Szegedi Tudományegyetem

Számítógépes Algoritmusok és Mesterséges Intelligencia

Tanszék

\title{
On-line elôrenézô és paraméter tanuló algoritmusok nyugtázási és ütemezési problémákra
}

Ph.D. értekezés

Németh Tamás

témavezetô:

Dr. Imreh Csanád

tanszékvezető egyetemi docens

SZTE TTIK, Informatika Doktori Iskola

Szeged, 2013 


\section{Köszönetnyilvánítás}

Mindenekelótt szeretnék köszönetet mondani Dr. Imreh Csanád tanszékvezetô egyetemi docensnek, témavezetômnek, aki nagy segítséget nyújtott a kezdetektôl fogva kutatásaim során, mind szakmai, mind kutatás-módszertani kérdésekben. A segítsége nélkül ez a mú nem születhetett volna meg.

Továbbá szeretnék köszönetet mondani Dr. Csendes Tibor professzor úrnak, az Informatika Doktori Program vezetőjének, és Dr. Csirik János professzor úrnak, hogy támogattak a doktori program évei alatt, és azóta is.

Köszönet illeti Nagy Sándor urat és Dr. Kókai Gabriellát†, a Fraunhofer Intézet munkatársait, hogy doktori tanulmányaim alatt, majd késóbb is lehetôséget biztosítottak, hogy részt vegyek az Intézet által végzett kutatásokban, és külön köszönöm Sándornak, a kutatásainkban való aktív részvételt és a sok segítséget. Köszönet illeti továbbá Gyekiczki Balázs tanítványomat, aki a félig on-line paraméter tanuló algoritmusok kutatásában segédkezett.

Köszönöm doktorandusz társaimnak és minden kollégámnak a sok segítő szándékú kritikát, javaslatot és támogatást.

Végül, de nem utolsó sorban szeretnék köszönetet mondani feleségemnek: Németh-Szabados Klára Viktóriának a tanulmányi és eddigi kutatási éveim alatt nyújtott rengeteg erkölcsi támogatásért és kislányomnak: Németh-Szabados Abigélnek, amiért jól tûrte az apa nélkülözését a hétköznapokban és a kutatással töltött hétvégéken is. 


\section{Tartalomjegyzék}

\section{Fejezet}

Bevezetés $\quad 4$

\section{Fejezet}

A nyugtázási probléma $\quad 8$

2.1. A nyugtázási probléma matematikai modellje . . . . . . . 9

2.2. Az optimális off-line algoritmus és az ébresztô algoritmus . 10

2.2.1. További eredmények a nyugtázási problémához . . 14

2.3. Előrenézố változatok versenyképességi elemzése . . . . . . 15

2.3.1. Az $f_{\max }$ célfüggvény . . . . . . . . . . 16

2.3.2. Az $f_{\text {sum }}$ célfüggvény . . . . . . . . . . . . 20

\section{Fejezet}

Paraméter tanuló algoritmusok a nyugtázási problémához

3.1. Jelölések és előzmények . . . . . . . . . . . . . . . . . 32

3.2. On-line paraméter tanuló algoritmus . . . . . . . . . . . 32

3.3. Az optimális $p$ érték meghatározása az Alarm $_{p}$ algoritmushoz 34

3.4. Az Learn Alarm $(r, q)$ algoritmus hatékonysági vizsgálata . 35

3.4.1. Tesztek valós adatokon . . . . . . . . . 36

3.4.2. Tesztek végrehajtása generált adatokon . . . . . . . 37

3.4.3. Következtetések . . . . . . . . . . . . . . . . 39

3.5. Félig on-line paraméter tanuló algoritmus . . . . . . . . . 40

3.6. Az algoritmusok értékelése . . . . . . . . . . . . . 43

3.6.1. A valós tesztadatok . . . . . . . . . . . . . . 43

3.6.2. Generált tesztadatok . . . . . . . . . . . 44 
3.6.3. Következtetések . . . . . . . . . . . . . . 47

\section{Fejezet}

Visszautasításos on-line ütemezés 48

4.1. Jelölések és előzmények . . . . . . . . . . . . . . . . . 50

4.2. Paraméter tanuló algoritmus . . . . . . . . . . . . . . 52

4.3. Hatékonysági vizsgálat . . . . . . . . . . . . 55

4.3.1. A végrehajtott tesztek ismertetése . . . . . . . 55

4.3.2. Az eredmények értékelése . . . . . . . . . . . . . 59

\section{Fejezet}

On-line klaszterezés egy RTLS rendszerben 61

5.1. Elốzmények . . . . . . . . . . . . . . . . . . 62

5.2. A probléma matematikai modellje . . . . . . . . . . 67

5.3. Versenyképességi elemzés . . . . . . . . . . . . . . . . . . . 69

5.3.1. Az általános modell . . . . . . . . . . . . . . . . . 69

5.3.2. A korlátos modell . . . . . . . . . . . . . . 71

5.4. Tapasztalati elemzés . . . . . . . . . . . . . 73

5.4.1. A VWT Algoritmus . . . . . . . . . . . . . 73

5.4.2. Hatékonysági vizsgálat . . . . . . . . . . 75

5.5. Áttekintés és nyitott kérdések . . . . . . . . . . . 78 


\section{Fejezet}

\section{Bevezetés}

Disszertációmban a 2006 óta, az on-line klaszterezési és ütemezési problémák területén végzett kutatásaim eredményeit gyújtöttem össze. Munkatársaimmal ezeken a területeken alapvetően két részterületet vizsgáltunk részletesebben. Az elsố az on-line klaszterezés témaköre, ezen belül is elsố sorban az on-line (és félig on-line) nyugtázási feladatot valamint egy, a mérési adatfolyamok valós idejű feldolgozásához definiált klaszterezési feladatot vizsgáltunk. A másik vizsgált témakör a párhuzamos gépes, visszautasításos on-line ütemezés problémaköre. Dolgozatomban számos új elméleti eredmény és sok alkalmazás, valamint az új algoritmusok valós körülmények közötti vizsgálata és azok eredményeinek ismertetése egyaránt megtalálható.

A gyakorlati problémákban gyakran fordulnak elő olyan optimalizálási feladatok, ahol a bemenetet (vagyis a feladatot definiáló számadatot) csak részenként ismerjük meg, és a döntéseinket a már megkapott információ alapján, a további adatok ismerete nélkül kell meghoznunk. Ilyen feladatok esetén on-line problémáról beszélünk. Az on-line algoritmusok elméletének igen sok alkalmazása van a számítástudomány, a közgazdaságtan és az operációkutatás különböző területein. Az elsô eredmények az on-line algoritmusok elméletének területérôl az 1970-es évekból származnak, majd a 90-es évek elejétól kezdve egyre több kutató kezdett el a területhez 
kapcsolódó problémák vizsgálatával foglalkozni. Számos részterület alakult ki és napjainkban is a legfontosabb, algoritmusokkal, operációkutatással foglalkozó konferenciákon rendszeresen ismertetnek új eredményeket ezen témakörökból.

Mivel egy on-line algoritmusnak részenként kell meghozni a döntéseit a teljes bemenet ismerete nélkül, ezért egy ilyen algoritmustól nem várhatjuk el, hogy az inputról teljes információval rendelkezô algoritmusok által megkapható optimális megoldást szolgáltassa. Azon algoritmusokat, amelyek ismerik a teljes bemenetet, off-line algoritmusoknak nevezzük.

Az on-line algoritmusok hatékonyságának vizsgálatára két alapvető módszert használnak. Az egyik lehetôség az átlagos eset elemzése. Ebben az esetben fel kell tételeznünk valamilyen valószínúségi eloszlást a lehetséges bemenetek terén, és a célfüggvénynek az erre az eloszlásra vonatkozó várható értékét vizsgáljuk. Ezen megközelítés hátránya, hogy általában nincs információnk arról, hogy a lehetséges bemenetek milyen valószínúségi eloszlást követnek.

A másik megközelítés egy legrosszabb eset elemzés, amelyet versenyképességi elemzésnek nevezünk. Ebben az esetben az on-line algoritmus által kapott megoldás célfüggvényértékét hasonlítjuk össze az optimális off-line célfüggvényértékkel. Egy on-line minimalizálási probléma esetén egy on-line algoritmust C-versenyképesnek nevezünk, ha tetszóleges bemenetre teljesül, hogy az algoritmus által kapott megoldás költsége nem nagyobb, mint az optimális off-line költség C-szerese. Egy algoritmus versenyképességi hányadosa a legkisebb olyan C szám, amelyre az algoritmus C-versenyképes. 
A továbbiakban egy tetszóleges ALG on-line algoritmusra az I bemeneten felvett célfüggvényértéket $A L G(I)$-vel jelöljük, az off-line célfüggvényértéket pedig $O P T(I)$-vel. Ezt a jelölésrendszert használva a versenyképességet minimalizálási problémákra a következésképpen definiálhatjuk. [7, 13, 26] Az ALG algoritmus C-versenyképes, ha $A L G(I) \leq$ $C \cdot O P T(I)$ teljesül minden I bemenet esetén. Szokás használni a versenyképesség egy további változatát is. Egy minimalizálási probléma esetén az ALG algoritmus enyhén C-versenyképes, ha van olyan B konstans, hogy $A L G(I) \leq C \cdot O P T(I)+B$ teljesül minden I bemenet esetén. Egy algoritmus enyhe versenyképességi hányadosa a legkisebb olyan C szám, amelyre az algoritmus enyhén C-versenyképes. Természetesen igaz, hogy ha egy algoritmus erôsen versenyképes valamely C konstanssal, akkor ezzel egyidejûleg ugyanezzel a konstanssal gyengén is versenyképes. A fentiekben a minimalizálási problémákra definiáltuk a versenyképességi analízis fogalmait. A definíciók hasonlóan értelmezhetőek maximalizálási problémák esetén is. Ekkor az ALG algoritmus C-versenyképes, ha $O P T(I) \leq C \cdot A L G(I)$ teljesül minden $I$ bemenet esetén, illetve enyhén Cversenyképes, ha valamely B konstans mellett $O P T(I) \leq C \cdot A L G(I)+B$ teljesül minden I bemenetre.

A versenyképességi elemzésen túl, további, a gyakorlat szempontjából igen fontos hatékonysági vizsgálati módszerek is léteznek. Az egyik ilyen, a gyakorlatban is jól alkalmazható módszer, az algoritmusok viselkedésének, hatékonyságának vizsgálata generált és valós inputokon. Ez a módszer megfelelő mérési módszer alkalmazása esetén az egyébként a valós körülmények között bonyolultsága miatt általában nehezen vagy 
egyáltalán nem alkalmazható átlagos eset elemzést helyettesítheti. A módszer lényege, hogy az adott célfüggvényértékeket kiszámítjuk a vizsgált algoritmusok futása során az adott inputokon, és kiszámítjuk rendre az adott inputra az optimális off-line célfüggvényértéket is. Az így kapott értékeket rendre összevetjük az on-line algoritmusok különböző inputon generált célfüggvényértékeivel. Ez a módszer úgy is alkalmazható, ha nem ismerjük az optimális off-line megoldást, ilyenkor a különböző on-line algoritmusok által generált célfüggvény-értékeket hasonlíthatjuk össze. 


\section{Fejezet}

\section{A nyugtázási probléma}

A számítógépes hálózatok elmélete az alkalmazások rendkívüli fontosságából adódóan az informatika egyik legjelentősebb kutatási területévé vált. A hálózatok tervezésénél és múködtetésük során számos optimalizálási feladat merül fel, mely feladatok többsége lényegében on-line, hiszen sem a forgalom, sem a hálózati topológia és egyéb paramétereinek esetleges változása nem látható elôre. A 90-es évek végétől az on-line algoritmusok területén dolgozó szakemberek on-line matematikai modelleket dolgoztak ki a számítógépes hálózatok témakörébe tartozó on-line feladatokra. A következő két fejezetben (és egy keveset az utolsó fejezetben is) ezzel a területtel foglalkozunk.

Az informatikai hálózatokon a kommunikáció során elküldött információ, csomagok formájában továbbítódik. Az esetek többségében azonban a kommunikációs csatorna nem teljesen megbízható (például az alkalmazott számítógépes hálózati infrastruktúrában vezeték nélküli komponensek is előfordulhatnak), ezért az egyes információcsomagok megérkezéséról a címzettnek nyugtát kell küldenie, így lehetôvé tehetô az elveszett csomagok újraküldése. A TCP implementációk is küldenek nyugtát a csomagok fogadásakor [38]. A nyugtázási probléma tárgyalása során azt próbáljuk meghatározni, hogy melyik idôpontban érdemes egy nyugtát küldeni. 
Abból indulunk ki, hogy egy nyugta több csomag megérkezését tudja igazolni, azonban ha túl sokáig várunk egy-egy nyugta elküldésével az a csomag újraküldéséhez vezethet, ami többletterhelést ró a hálózatra, míg ha minden csomagot azonnal nyugtázunk akkor maguk a nyugták terhelik feleslegesen a hálózatot.

Az első on-line optimalizációs modell, mely a nyugták küldésének optimális idốpontját próbálja meghatározni Dolly, Goldman és Scott fejlesztették ki 1998-ban [14]. Ebben a modellben minden csomagnak van egy beérkezési idôpontja és az algoritmusnak valós időben kell döntenie a nyugta küldésérôl úgy, hogy a jövőben érkező csomagokról nincs egyéb információja.

\subsection{A nyugtázási probléma matematikai modellje}

A nyugtázási probléma matematikai modelljében a bemenet az egyes csomagok $a_{1}, \ldots, a_{n}$ érkezési ideje. Az algoritmusnak meg kell határoznia, hogy mikor küld nyugtákat, ezeket az idốpontokat $t_{1}, \ldots, t_{k}$ jelöli. A nyugtázási probléma költségfüggvénye:

$$
\gamma k+(1-\gamma) \sum_{j=1}^{k} v_{j},
$$

ahol k a nyugták száma és $v_{j}$ a nyugtákhoz tartozó késedelmet jelöli, $\gamma$ pedig egy, a feladat által meghatározott paraméter. Amennyiben $v_{j}=$ $\sum_{t_{j-1}<a_{i} \leq t_{j}}\left(t_{j}-a_{i}\right)$, a j-edik nyugta által összegyújtött teljes késedelem, akkor az $f_{\text {sum }}$ modellról beszélünk. Ha $v_{j}=\max _{t_{j-1}<a_{i} \leq t_{j}}\left(t_{j}-a_{i}\right)$, a 
j-edik nyugta által összegyújtött maximális késedelem, akkor az $f_{\max }$ modellrôl beszélünk. A probléma on-line, azaz egy adott t idôpontban csak a t-ig megérkezett csomagok érkezési idejét ismerjük és nincs semmi információnk a további csomagokról.

\subsection{Az optimális off-line algoritmus és az ébresztő al- goritmus}

\section{Az off-line algoritmus}

Az $f_{\text {sum }}$ modellben az optimális off-line célfüggvény értéket az alábbi algoritmus szolgáltatja [14].

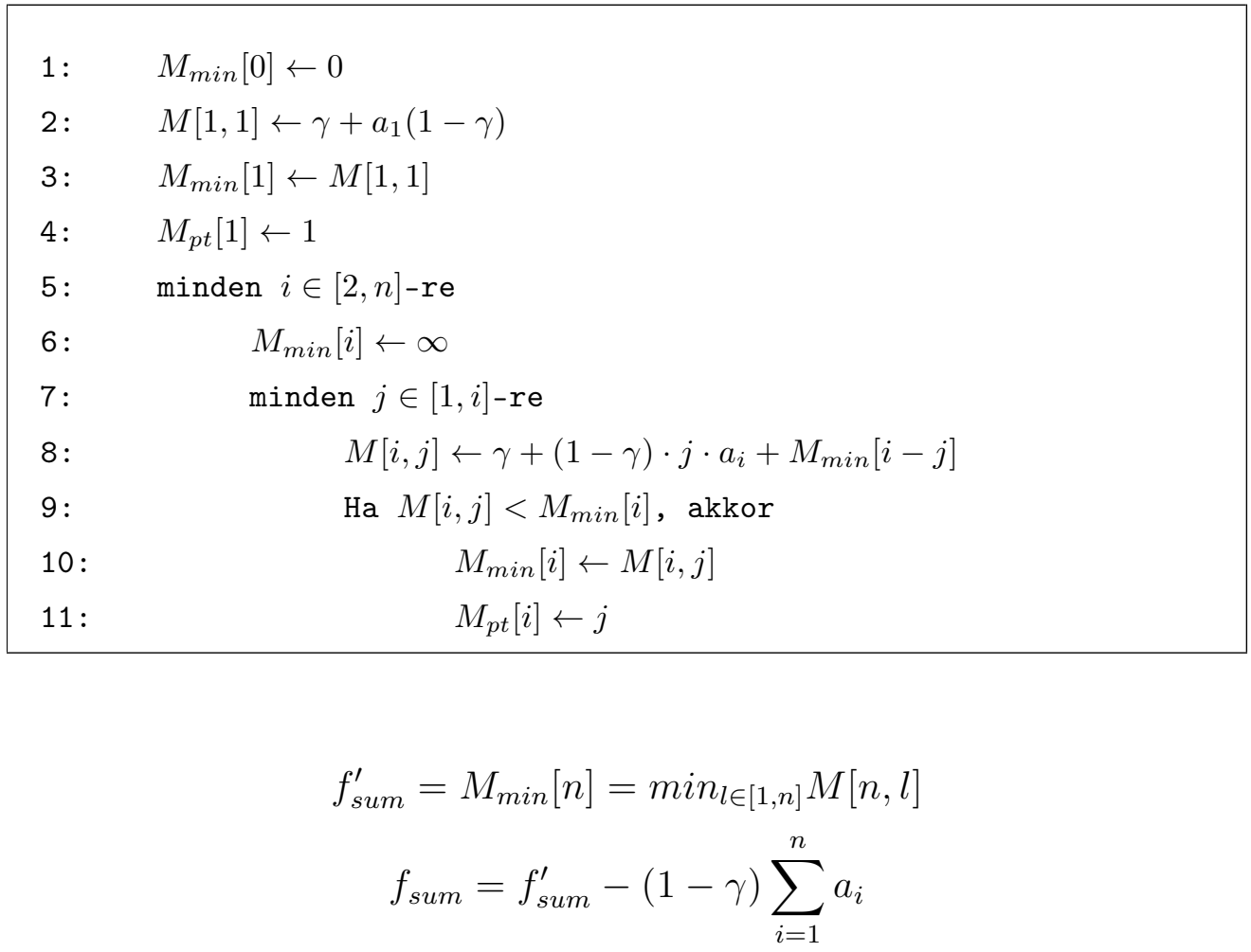


Az off-line algoritmust valós körülmények között nem tudjuk használni, hiszen nincs információnk előre az egyes csomagok érkezési időpontjairól. A tesztek végrehajtásához azonban szükséges a célfüggvény optimális értékét is kiszámolnunk, hogy az on-line algoritmus által elért célfüggvény értéket össze tudjuk vetni a célfüggvény optimális off-line értékével. Ezt a gyakorlatban úgy lehet kivitelezni, hogy a tesztek futása során az online érkezô adatcsomagok érkezési idôpontjait mentjük egy fájlba vagy adatbázisba, és késóbb ezekre az értékekre számítjuk ki, hogy mi lett volna az optimális off-line célfüggvény érték.

\section{Az on-line ébresztő algoritmus}

Az on-line probléma megoldására az ébresztő beállításán alapuló algoritmusokat [14] dolgoztak ki. Egy ébresztô algoritmus a következôképpen múködik. Az $a_{j}$ csomag érkezésekor beállítunk egy ébresztôt valamilyen $a_{j}+e_{j}$ időpontra. Ha az $a_{j}+e_{j}$ idôpontig nem érkezik új csomag, akkor az $a_{j}+e_{j}$ idôpontban nyugtát küldünk, egyébként az $a_{j+1}$ érkezésekor átállítjuk az ébresztôt, egy $a_{j+1}+e_{j+1}$ idôpontra. Az alábbiakban egy ébresztő algoritmust elemzünk részletesebben, azt az algoritmust, amely úgy állítja be az ébresztôt, hogy az elsố nyugtázatlan csomagtól legyen a teljes késedelem költsége 1. Ezt az algoritmust ébresztô algoritmusnak nevezzük. A fenti szabály azt jelenti, hogy az általános definícióban az $e_{j}$ érték a következő egyenlet megoldása:

$$
1=\left|\sigma_{i}\right| e_{j}+\sum_{a_{i} \in \sigma_{i}}\left(a_{j}-a_{i}\right)
$$


ahol $\sigma_{j}$ az $a_{j}$ csomag érkezése után meglevô még nyugtázatlan csomagok halmaza.

Az ébresztô algoritmusra az $f_{\text {sum }}$ modellben a következő tulajdonságok teljesülnek. Az alábbiakban a bizonyítások alapötletét is bemutatjuk a speciális $\gamma=1 / 2$ esetre, mivel a késóbbiekben ezeket a bizonyításokat fogjuk kiterjeszteni az általánosabb modellre.

1. Prepozíció. ([14]) Az $f_{\text {sum }}$ modellben az ébresztố algoritmus versenyképességi hányadosa 2.

Bizonyítás: Vegyünk egy tetszóleges inputot és tegyük fel, hogy az ébresztô algoritmus $k$ darab nyugtát küld. Ezek a nyugták $k$ darab intervallumot határoznak meg. Az algoritmus költsége legfeljebb $2 k$, hiszen $k$ a nyugtákból keletkezô költség, és az algoritmus úgy állítja be az ébresztôt, hogy a teljes késedelemból adódó költség minden nyugtára pontosan 1 legyen. Legyen $k^{*}$ az optimális off-line algoritmus által küldött nyugták száma. Ha $k^{*} \geq k$, akkor $O P T(I) \geq k$ és adódik, hogy az algoritmus valóban 2-versenyképes. Amennyiben $k^{*}<k$, akkor az ébresztő algoritmus nyugtái által meghatározott $k$ közül legalább $k-k^{*}$ intervallumban OPT-nak nincs nyugtája, ez legalább $k-k^{*}$ késedelemból származó költséget jelent OPT számára, így ismét $O P T(I) \geq k$ adódik, amely egyenlootlenségból következik, hogy az algoritmus 2-versenyképes.

2. Prepozíció. ([14]) A nyugtázási problémára az $f_{\text {sum }}$ modellben nem létezik olyan on-line algoritmus melynek 2-nél kisebb a versenyképességi hányadosa. 
Bizonyítás: Vegyünk egy tetszóleges on-line algoritmust, jelölje ONL. Tekintsük a következô bemenetet. Vegyük csomagok egy hosszú sorozatát, amelyet úgy kapunk, hogy minden esetben, amikor ONL egy nyugtát küld azonnal egy új csomag érkezik, de addig nem jött új csomag. A számítások egyszerűsítéséhez feltesszük, hogy az új csomag érkezéséig eltelő nagyon rövid idő 0, ennek ellenére az új csomagot a nyugta nem nyugtázza. (Ez a feltétel elkerülhetô lenne kicsi $\varepsilon>0$ értékek használatával.) Ekkor egy $2 n$ csomagból álló sorozat esetén az on-line algoritmus költsége $O N L\left(I_{2 n}\right)=$ $2 n+t_{2 n}$, hiszen a nyugtákból adódó költsége $2 n$, és az $i$-edik nyugtánál fellépő késedelem $t_{i}-t_{i-1}$, ahol a $t_{0}=0$ értéket használjuk.

Vizsgáljuk meg a következô két algoritmust, ODD a páros sorszámú csomagok után küld nyugtát, EV pedig a páratlan sorszámú csomagok és közvetlenül az utolsó, 2n-edik csomag után. Ekkor ezen algoritmusok költségei

$$
E V\left(I_{2 n}\right)=n+\sum_{i=0}^{n-1}\left(t_{2 i+1}-t_{2 i}\right)+1
$$

és

$$
O D D\left(I_{2 n}\right)=n+\sum_{i=0}^{n-1}\left(t_{2 i}-t_{2 i-1}\right) .
$$

Innen következik, hogy $E V\left(I_{2 n}\right)+O D D\left(I_{2 n}\right)=O N L\left(I_{2 n}\right)+1$. Másrészt az optimális off-line algoritmusra

$$
O P T\left(I_{2 n}\right) \leq \min \left\{E V\left(I_{2 n}\right), O D D\left(I_{2 n}\right)\right\}
$$

így azt kapjuk, hogy

$$
O N L\left(I_{2 n}\right) / O P T\left(I_{2 n}\right) \geq 2-1 / O P T\left(I_{2 n}\right) .
$$

Ezen egyenlőtlenség alapján adódik, hogy ONL nem lehet jobb, mint 
2-versenyképes, hiszen a csomagok egy elegendően hosszú sorozatát véve az $\operatorname{OPT}\left(I_{2 n}\right)$ érték tetszólegesen nagy lehet.

Hasonló módon igazolhatók az $f_{\max }$ modellre az alábbi eredmények.

3. Prepozíció. ([14]) Az $f_{\max }$ modellben az ébresztố algoritmus versenyképességi hányadosa 2.

4. Prepozíció. ([14]) A nyugtázási problémára az $f_{\text {max }}$ modellben nem létezik olyan on-line algoritmus melynek 2-nél kisebb a versenyképességi hányadosa.

\subsubsection{További eredmények a nyugtázási problémához}

Számos további eredményt publikáltak a nyugtázás területéról. A probléma off-line verziójában az $f_{\text {sum }}$ célfüggvényt vizsgálták [34] ahol egy gyors, lineáris futási idejú algoritmust mutattak be. Véletlenített online algoritmusokat is vizsgáltak [29, 35] a területen, továbbá publikáltak [29] egy $e /(e-1)$-versenyképes algoritmust is a probléma megoldására. Bizonyították, hogy nem létezik olyan on-line véletlenített algoritmus [35] a probléma megoldására, aminek $e /(e-1)$-nél kisebb a versenyképességi hányadosa.

Néhány további célfüggvényt is vizsgáltak [1] és [22].

Az [1] cikkben olyan matematikai modellt mutattak be, melyben a célfüggvény értéke a nyugták számának és a nyugták által összegyújtött maximális késedelemnek az összege. Az általános modellben a maximális 
késedelem p-edik hatványát vizsgálták. Mindkét esetre optimális on-line algoritmust mutattak be. A $p=1$ esetben az algoritmus versenyképességi hányadosa $\pi^{2} / 6$, az általános esethez a versenyképességi arányt egy Riemann zéta függvény adja meg, mely 1.5-höz tart, ha $p$ tart végtelenbe. A cikk a véletlenített algoritmusokkal elérhető versenyképességi hányados alsó korlátját is bizonyítja. További célfüggvényt is bemutattak [22] az $f_{\max }$ általánosítására, mely szintén használja a nyugták küldése közötti idôtartamok felső korlátját. Ebből a cikkból egy optimális $(1+\sqrt{5}) / 2$-versenyképes determinisztikus, és szintén optimális $(\sqrt{3}+1) / 2$-versenyképes véletlenített algoritmust is megismerhetünk, továbbá bemutatnak az algoritmusok egy olyan osztályát, mely algoritmusok számára csak korlátozott számú véletlen bit használata megengedett. A nyugtázási probléma egy még általánosabb modelljét [17] is megismerhetjük, mely on-line probléma motivációja a híváskezelő rendszerek múködtetéséból származik, ahol a két ügyfél kezelésének esete a nyugtázási probléma egy általánosítása.

\subsection{Elốrenézô változatok versenyképességi elemzése}

A félig on-line algoritmusok néhány elöretekintő tulajdonságot is figyelembe vesznek. A legtöbb alkalmazásban az algoritmusok on-line-ok, azaz a további csomagokat illetően nem rendelkeznek előretekintô információval. Ennek ellenére az elôretekintô algoritmusok vizsgálata is fontos probléma [14]. Az ilyen algoritmusok vizsgálata annak a megértésében is segít, hogy hogyan használhatják az egyes tanuló algoritmusok a további csomagok érkezésének becslését. Az $f_{\max }$ célfüggvény esetén ha 
tudjuk a következő csomag érkezési idejét, úgy 1 versenyképes algoritmus adható, viszont az $f_{\text {sum }}$ célfüggvény esetében, a következô $k$ csomag érkezési idejének ismerete sem elég (bármely $k$ konstansra), hogy 2-nél jobb versenyképességi hányadost kapjunk.

Vizsgáljunk meg egy másik előretekintő tulajdonságot! Tegyük fel, hogy az algoritmus az érkezési időket nem a következô $k$ csomagra, hanem a következő $c$ hosszúságú időintervallumra ismeri. Az ilyen típusú előretekintő tulajdonságot idő előretekintő tulajdonságnak nevezzük, ezt vizsgálták például on-line jármú útvonaltervezô problémára [3] is.

Az on-line probléma $t$ időpontjában az algoritmus ismeri a már megérkezett csomagok érkezési idejét, de nincs információja az érkezési idókről a további csomagokat illetôen. Az alábbiakban bemutatunk egy idôelőretekintô tulajdonságú félig on-line modellt, ahol $t$ időpontban a az algoritmus ismeri a már megérkezett csomagok érkezési idejét, továbbá $\mathrm{a}(t, t+c]$ időintervallumban érkezô csomagok érkezési idejét is. A továbbiakban $\sigma_{i}$-vel jelöljük az $a_{i}$ időpontban még nyugtázatlan csomagok halmazát. A csomagok tetszóleges $L$ sorozatára és egy $A$ algoritmusra, $A(L)$ az algoritmus által küldött nyugták összes költségét jelöli, az optimális költséget $L$ listára $O P T(L)$ jelöli. Az algoritmusok értékelésére versenyképességi elemzést alkalmazzuk.

\subsubsection{Az $f_{\max }$ célfüggvény}

Ahogy azt a fentiekben definiáltuk az $f_{\max }$ célfüggvényt úgy kapjuk, ha $L_{j}=\max _{t_{j-1}<a_{i} \leq t_{j}}\left(t_{j}-a_{j}\right)$, azaz a $j$. nyugta által összegyújtött maximális 
késedelem. Így a célfüggvényünk:

$$
\gamma k+(1-\gamma) \sum_{j=1}^{k} \max _{t_{j-1}<a_{i} \leq t_{j}}\left(t_{j}-a_{j}\right) .
$$

\section{Az algoritmus}

Az $f_{\text {max }}$ célfüggvény alkalmazása esetén optimális megoldást kapunk, ha a $a_{j}$ idôpontbeli nyugtát akkor és csak akkor küldjük, ha $a_{j+1}-a_{j} \geq$ $\gamma /(1-\gamma)$. Így két esetet kell megvizsgálnunk, $c$ értékétől függôen. Ha $c \geq \gamma /(1-\gamma)$, akkor könnyen megadhatunk egy 1-versenyképes algoritmust is. Ekkor ugyanis az előretekintési intervallum mérete elég nagy ahhoz, hogy eldöntsük, az $a_{j+1}-a_{j} \geq \gamma /(1-\gamma)$ egyenlőtlenség igaz, vagy hamis, tehát az előrenézố algoritmusunk az optimális megoldást adja. Sokkal érdekesebb, amikor $c<\gamma /(1-\gamma)$. Ebben az esetben az ébresztô algoritmus egy kiterjesztett verzióját használjuk, amit a továbbiakban TLA algoritmusnak nevezünk (Time Lookhead Alarming algorithm). Az algoritmus a következóképpen múködik. Az $a_{j}$ időpontban beállítjuk az ébresztőt $a_{j}+\gamma /(1-\gamma)-c$ időpontra. Ha az $a_{j+1}$ csomag az ébresztési időpont előtt megérkezik vagy ha az $a_{j+1}$ csomagot az $a_{j}+\gamma /(1-\gamma)-c$ idôpontban az $\left(a_{j}+\gamma /(1-\gamma)-c, a_{j}+\gamma /(1-\gamma)\right]$ intervallumban látjuk (előre) akkor átállítjuk az ébresztôt az $a_{j+1}+\gamma /(1-\gamma)-c$ idôpontra. Ellenkező esetben, azaz ha nem érkezik meg a következő csomag az $\left(a_{j}, a_{j}+\right.$ $\gamma /(1-\gamma)$ ] időintervallumban, akkor nyugtát küldünk az $a_{j}+\gamma /(1-\gamma)-c$ idôpontban, mely az összes még nyugtázatlan csomagot nyugtázza.

1. Tétel. ([27]) A TLA algoritmus $\max \left\{1,2-\frac{1-\gamma}{\gamma} c\right\}$-versenyképes. 
Bizonyítás: Először azt mutatjuk meg, hogy az algoritmus $2-\frac{1-\gamma}{\gamma} c-$ versenyképes. Vegyünk egy tetszóleges $a_{1}, \ldots, a_{n}$ inputot. Particionáljuk az input sorozatot részsorozatokra (fázisokra) a következóképpen: Legyen $S_{1}=\left\{a_{1}, \ldots, a_{k(1)}\right\}$ ahol $k(1)$ az elsó index melyre $a_{k(1)+1}-a_{k(1)} \geq$ $\gamma /(1-\gamma)$. A többi fázist is hasonló módon definiáljuk, azaz $S_{j+1}=$ $\left\{a_{k(j)+1}, \ldots, a_{k(j+1)}\right\}$, ahol $k(j+1)$ az elsó index a $k(j)$ után, melyre $a_{k(j+1)+1}-a_{k(j+1)} \geq \gamma /(1-\gamma)$. Az utolsó fázis az utolsó csomaggal zárul, továbbá legyen $\mathrm{k}(0)=0$.

Ekkor az optimális off-line algoritmus minden fázis utolsó csomagjánál küld egy-egy nyugtát, ezért az algoritmus összes költsége a $j$. nyugtánál

$$
O P T\left(S_{j}\right)=\gamma+(1-\gamma)\left(a_{k(j)}-a_{k(j-1)+1}\right) .
$$

A TLA algoritmus viszont $a_{k(j)}+\gamma /(1-\gamma)-c$ idôpontban küldi a nyugtát, így a $j$. csomagnál az összes költség:

$$
T L A\left(S_{j}\right)=\gamma+(1-\gamma)\left(a_{k(j)}+\gamma /(1-\gamma)-c-a_{k(j-1)+1}\right) .
$$

Mivel $T L A\left(S_{j}\right) / O P T\left(S_{j}\right)>1$, ezért ha a számlálót és a nevezőt is csökkentjük ugyanazzal a konstanssal, akkor a hányados értéke növekszik, így azt kapjuk, hogy

$$
\frac{T L A\left(S_{j}\right)}{O P T\left(S_{j}\right)} \leq \frac{\gamma+(1-\gamma)(\gamma /(1-\gamma)-c)}{\gamma}=2-\frac{1-\gamma}{\gamma} c .
$$

A teljes költség viszont a partíciók költségeinek összege, így TLA $2-\frac{1-\gamma}{\gamma} c$ -versenyképes.

\section{Alsó korlát}

A TLA algoritmus optimális, azaz nem létezik olyan algoritmus, amelynek kisebb a versenyképességi hányadosa. 
2. Tétel. Nem létezik olyan c-elórenézô félig on-line algoritmus a nyugtázási problémára az $f_{\max }$ modellben, amelynek kisebb a versenyképességi hányadosa, mint $\max \left\{1,2-\frac{1-\gamma}{\gamma} c\right\}$.

Bizonyítás: Ha $c \geq \gamma /(1-\gamma)$ akkor az állítás nyilvánvalóan igaz, így feltételezhetjük, hogy $c<\gamma /(1-\gamma)$. Tekintsünk egy tetszóleges $A$ online algoritmust. A következô inputot definiáljuk, jelöljük $I_{n}$-el. Az első csomag érkezési ideje $a_{1}=0$. Az $i$. csomag $(i=2, \ldots, n)$ az $i-1$. csomag nyugtája után $c$ időegység múlva érkezik $\left(a_{i}=t_{i-1}+c\right)$.

Partícionáljuk az inputot a 2. tételnél látottakhoz hasonlóan. Az egyes fázisokat $S_{1}, \ldots, S_{j}$-vel jelöljük. Most tekintsük $S_{i}$ fázist. Az egyszerüség kedvéért $k(i)-k(i-1)$ értéket $r_{i}$-vel jelöljük. Az $A$ algoritmus minden csomagot nyugtáz, így azt kapjuk, hogy

$$
A\left(S_{i}\right)=\gamma r_{i}+(1-\gamma) \sum_{p=k(i-1)+1}^{k(i)}\left(t_{p}-a_{p}\right) .
$$

Az optimális megoldás ellenben mindössze egyetlen nyugtát küld, az $a_{k(i)}$ időpontban, így

$$
O P T\left(S_{i}\right)=\gamma+(1-\gamma)\left(\sum_{p=k(i-1)+1}^{k(i)-1}\left(t_{p}-a_{p}\right)+c\left(r_{i}-1\right)\right) .
$$

Most tegyük fel, hogy $i<j$. Ha kiszámoljuk az $A\left(S_{i}\right)-\left(2-\frac{1-\gamma}{\gamma} c\right) O P T\left(S_{i}\right)$ értéket és felhasználjuk, hogy $t_{p}-a_{p} \leq \gamma /(1-\gamma)-c$, minden $p=$ $k(i-1)+1, \ldots, k(i)-1$ és azt, hogy $t_{k(i)}-a_{k(i)}>\gamma /(1-\gamma)-c$, akkor azt kapjuk, hogy

$$
A\left(S_{i}\right)-\left(2-\frac{1-\gamma}{\gamma} c\right) O P T\left(S_{i}\right) \geq \gamma\left(r_{i}-2+\frac{1-\gamma}{\gamma} c\right)+(1-\gamma)
$$




$$
\begin{aligned}
& \left(\left(\frac{1-\gamma}{\gamma} c-2\right)\left(r_{i}-1\right) c+\left(r_{i}-1\right)\left(\frac{1-\gamma}{\gamma} c-1\right)\left(\frac{\gamma}{1-\gamma}-c\right)+\frac{\gamma}{1-\gamma}-c\right) \\
& =\gamma\left(r_{i}-2+\frac{1-\gamma}{\gamma} c\right)-(1-\gamma)\left(r_{i}-1\right) c+\left(r_{i}-1\right)((1-\gamma) c-\gamma)+\gamma-c(1-\gamma)=0
\end{aligned}
$$

Így bizonyítottuk, hogy $A\left(S_{i}\right) \geq\left(2-\frac{1-\gamma}{\gamma} c\right) O P T\left(S_{i}\right)$ ha $i<j$. Az $S_{j}$ esetében egyetlen különbség van. Ekkor a $t_{k(j)}-a_{k(j)}>\gamma /(1-\gamma)-c$ egyenlőtlenség nem áll fenn, viszont ugyanígy beláthatjuk, hogy

$$
A\left(S_{j}\right)+\gamma /(1-\gamma)-c \geq\left(2-\frac{1-\gamma}{\gamma} c\right) O P T\left(S_{j}\right)
$$

Mivel a teljes költség az egyes fázisokon számított költségek összege, így $A\left(I_{n}\right)+\gamma /(1-\gamma)-c \geq\left(2-\frac{1-\gamma}{\gamma} c\right) O P T\left(I_{n}\right)$. Továbbá ha $n$ tart végtelenbe $\mathrm{OPT}\left(I_{n}\right)$ is a végtelenbe tart, így a fenti egyenlőtlenség szerint $A\left(I_{n}\right) / O P T\left(I_{n}\right)$ hányados $2-\frac{1-\gamma}{\gamma} c$-hez tart, tehát $A$ versenyképességi hányadosa nem lehet kisebb mint $2-\frac{1-\gamma}{\gamma} c$.

\subsubsection{Az $f_{\text {sum }}$ célfüggvény}

Mint azt a fentiekben definiáltuk, az $f_{\text {sum }}$ célfüggvényt úgy kapjuk, ha $L_{j}=\sum_{t_{j-1}<a_{i} \leq t_{j}}\left(t_{j}-a_{j}\right)$, azaz a $j$. nyugta által összegyújtött összes késedelem. Így a célfüggvényünk:

$$
\gamma k+(1-\gamma) \sum_{j=1}^{k} \sum_{t_{j-1}<a_{i} \leq t_{j}}\left(t_{j}-a_{j}\right) .
$$

\section{A TLA algoritmus}

Ebben a részben is kézenfekvô ötlet az ébresztô algoritmus [14] idôelőretekintő kiterjesztését használni. Most a következőképpen definiáljuk 
az ébresztố algoritmus idő-elôretekintô változatát. Az $a_{j}$ csomag megérkezésének pillanatában beállítjuk az ébresztôt $a_{j}+e_{j}$ idôpontra, ahol $e_{j}=\left(\gamma /(1-\gamma)-\sum_{a_{i} \in \sigma_{j}}\left(a_{j}-a_{i}\right)\right) /\left|\sigma_{j}\right|$. Ha a következó csomag $\left(a_{j+1}\right)$ a $\max \left\{a_{j}, a_{j}+e_{j}-c\right\}$ időpont előtt megérkezik vagy látjuk $a_{j+1}$ csomagot az elôretekintő időintervallumban, akkor lépjünk következô csomaghoz és állítsuk be újra az ébresztôt a fent leírt módon. Ellenkezô esetben (nem érkezik csomag az $\left.\left(a_{j}, a_{j}+e_{j}\right]\right)$ intervallumban, küldünk egy nyugtát a $\max \left\{a_{j}, a_{j}+e_{j}-c\right\}$ időpontban mely az összes még nyugtázatlan csomagot nyugtázza. Sajnos a fenti algoritmus nem ér el kisebb versenyképességi hányadost mint 2 .

3. Tétel. Tetszóleges c-re a TLA algoritmus versenyképességi hányadosa 2 .

Bizonyítás: Az algoritmus versenyképességi hányadosa nem nagyobb mint az ébresztő algoritmus versenyképességi hányadosa [14], tehát a TLA algoritmus versenyképesési hányadosa nem nagyobb mint 2, mivel az ébresztő algoritmus 2 versenyképes. Viszont nincs kisebb versenyképességi hányadosa sem, amit az alábbi inputon láthatunk.

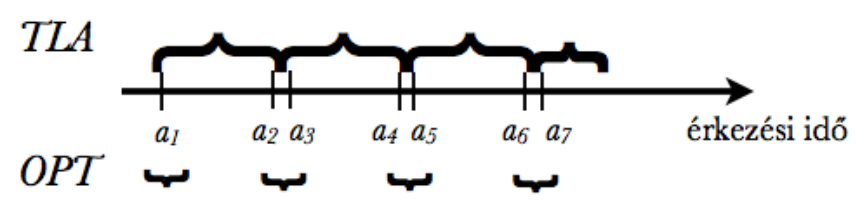

1. ábra. A TLA és OPT viselkedése 
Legyen $I_{n}=\left\{a_{1}, \ldots, a_{2 n+1}\right\}$ ahol $a_{1}=0$ és $a_{2 i}=i \gamma /(1-\gamma)+(i-1) \varepsilon$, $a_{2 i+1}=i \gamma /(1-\gamma)+i \varepsilon, i=1, \ldots, n$. Ekkor $T L A$ a következő időpontokban küldi a nyugtákat: $a_{2}, \ldots, a_{2 n}, \max \left\{a_{2 n+1}, a_{2 n+1}+\gamma /(1-\gamma)-c\right\}$. Így $T L A\left(I_{n}\right)=(n+1) \gamma+n \gamma+(1-\gamma) \max \{0, \gamma /(1-\gamma)-c\}$. Egy optimális off-line algoritmus $a_{1}, a_{3}, a_{2 n+1}$ időpontokban küldi a nyugtákat, ennek költsége $O P T\left(I_{n}\right)=(n+1) \gamma+(1-\gamma) n \varepsilon$. A versenyképességi hányados így 2-höz tart, ha $\varepsilon$ tart a 0 -hoz és $n$ tart végtelenbe, ebból következik, hogy a versenyképességi hányados legalább 2.

\section{A LIP algoritmus}

Ha $c>\gamma /(1-\gamma)$ 2-nél kisebb versenyképességú algoritmust is adhatunk. A LIP algoritmus (Lookahead Interval Planning algorithm) a következô. Az algoritmus blokkokra bontja az inputot, majd minden blokkra meghatározza a nyugták küldésének idôpontját az optimális offline algoritmus segítségével. Egy-egy blokk mindig az első nyugtázatlan csomaggal kezdődik. Az algoritmus először meghatározza, hogy van-e 2 egymást követő csomag a $c$ hosszúságú elôretekintő intervallumban melyre $a_{i+1}-a_{i}>\gamma /(1-\gamma)$. Ha van ilyen pár, a blokkot lezárjuk az elsô ilyen $a_{i}$ idôpontnál, egyébként a blokk intervallumának hossza $c$. Ez után az algoritmus meghatározza a blokkra a nyugták küldésének időpontját az optimális megoldáshoz az off-line probléma optimális megoldásával [14], majd elküldi a nyugtákat a megoldás szerint és áttér a következô blokkra.

4. Tétel. A LIP algoritmus $1+\frac{\gamma}{(1-\gamma) c}$-versenyképes.

Bizonyítás: A fenti tétel belátásához vegyünk egy tetszóleges $I$ inputot! Bontsuk blokkokra az inputot úgy, ahogy azt az algoritmus leírásánál 
megadtuk. Figyeljük meg, hogy létezik egy optimális off-line algoritmus mely minden blokkban küld egy nyugtát a blokk utolsó csomagjánál. (Mert ha a blokk utolsó csomagja késik, akkor a késés költsége több mint $(1-\gamma)(\gamma /(1-\gamma))=\gamma$, és a nyugtázás költsége pontosan $\gamma$.) Továbbá vegyük észre, hogy az utolsó csomag mindig egy blokk utolsó csomagja egyben és LIP is küld nyugtát a blokk utolsó csomagjánál.

Tekintsünk egy tetszôleges fázist, $S_{i}$-t. Jelöljük $r$-rel a fázisban található blokkok számát. Vegyük a fázison az optimális off-line megoldást. Ha hozzáveszünk $r-1$ további nyugtát az elsô $r-1$ blokk végéhez, olyan megoldást kapunk, amely a blokkokat külön-külön nyugtázza. De LIP a legjobb ilyen megoldást adja, ezért azt kapjuk, hogy $(r-1) \gamma+O P T\left(S_{i}\right) \geq$ $\operatorname{LIP}\left(S_{i}\right)$, tehát $\operatorname{LIP}\left(S_{i}\right) / O P T\left(S_{i}\right) \leq 1+(r-1) \gamma / O P T\left(S_{i}\right)$.

Határozzuk meg $O P T\left(S_{i}\right)$ értékét. Mivel minden blokk azonos fázisban van és minden blokk hossza legalább $c$, a fázis hossza legalább $(r-1) c$. Tegyük fel, hogy az optimális off-line algoritmus $k$ nyugtát küld ebben a fázisban. Ekkor az első $k-1$ nyugta után van egy legfeljebb $\gamma /(1-\gamma)$ hosszú időintervallum mely idô alatt nem érkezik csomag. Ebból következik, hogy a teljes optimális költség legalább $(1-\gamma)((r-1) c-(k-1) \gamma /(1-\gamma))$. Így $O P T\left(S_{i}\right) \geq k \gamma+(1-\gamma)((r-1) c-(k-1) \gamma /(1-\gamma))=(1-\gamma)(r-1) c+\gamma$. Ezt használva kapjuk, hogy $\operatorname{LIP}\left(S_{i}\right) / \operatorname{OPT}\left(S_{i}\right) \leq 1+\frac{\gamma}{(1-\gamma) c}$.

\section{Alsó korlátok}

Először adunk egy alsó korlátot a versenyképességi hányados nagyságrendjére. Ez megmutatja, hogy az $f_{\text {sum }}$ célfüggvény esetében nem 
létezik olyan konstans méretû előretekintés, amely segítségével elérhetô az 1-versenyképesség.

5. Tétel. Nem létezik olyan c-elórenézô félig on-line algoritmus a nyugtázási problémára az $f_{\text {sum }}$ modellben, amelynek kisebb a versenyképességi hányadosa, mint $1+\Omega\left(1 / c^{2}\right)$.

Bizonyítás:

A számítások egyszerûsítése érdekében feltesszük, hogy $c=\gamma(k-$

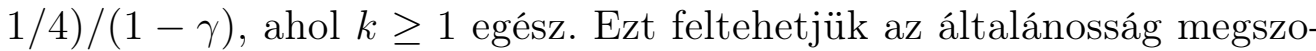
rítása nélkül, mert egy nagyobb előretekintés nem tudja csökkenteni a versenyképességi hányadost. Tekintsünk egy tetszőleges $c$-előrenéző $A$ algoritmust. Legyen $x=\frac{\gamma(2 k+1)}{4 k(1-\gamma)}$ és $y=\gamma / 2(1-\gamma)$. A következő sorozatokat definiáljuk minden $j=1, \ldots, k$-ra.

- $S_{x j x}=\left\{a_{1}, a_{2}, \ldots, a_{2 j}\right\}$, ahol $a_{2 i-1}=(i-1) x+(i-1) y$ és $a_{2 i}=$ $i x+(i-1) y, i=1, \ldots, j$. Vegyük észre, hogy $a_{2 k}=c$ az $S_{x k x}$ sorozatban.

- $S_{x j y}=\left\{a_{1}, a_{2}, \ldots, a_{2 j+1}\right\}$, ahol $a_{2 i-1}=(i-1) x+(i-1) y, i=$ $1, \ldots, j+1$ és $a_{2 i}=i x+(i-1) y, i=1, \ldots, j$

- $S_{y j y}=\left\{a_{1}, a_{2}, \ldots, a_{2 j}\right\}$, ahol $a_{2 i-1}=(i-1) y+(i-1) x$ és $a_{2 i}=$ $i y+(i-1) x, i=1, \ldots, j$.

- $S_{y j x}=\left\{a_{1}, a_{2}, \ldots, a_{2 j+1}\right\}$, ahol $a_{2 i-1}=(i-1) y+(i-1) x, i=$ $1, \ldots, j+1$ és $a_{2 i}=i y+(i-1) x, i=1, \ldots, j$.

A $\gamma+(1-\gamma)(2 y+x)=2 \gamma+(1-\gamma) x$ egyenletból azt kapjuk, hogy van olyan optimális megoldás a fent leírt sorozatokra, mely soha nem nyugtáz 
2 csomagnál többet egyetlen nyugtával. Ezt a megfigyelést felhasználva igazoljuk az alábbi lemmát.

1. Lemma. Minden j-re $(1 \leq j \leq k)$ : $O P T\left(S_{x j y}\right)=O P T\left(S_{y j x}\right)=\gamma(j+$ $1)+(1-\gamma) j y, O P T\left(S_{x j x}\right)=\gamma j+(1-\gamma) j x, O P T\left(S_{y j y}\right)=\gamma j+(1-\gamma) j y$.

Bizonyítás: Az állítást teljes indukcióval igazoljuk. Elsóként vegyük a $k=1$ esetet. Az $S_{x 1 y}$ sorozatban az érkezési idők $0, x, x+y$, az $S_{x 1 y}$ sorozatban az érkezési idôk $0, y, x+y$ és az optimális megoldás mindkét esetben két nyugtát küld, $S_{x 1 y}$ esetén a 0 és az $x+y$ idôpontokban, $S_{x 1 y}$ esetén pedig az $y$ és az $x+y$ idôpontokban. Így a késedelem mindkét esetben $y$. Az $S_{x 1 x}$ és $S_{y 1 y}$ sorozatok esetén mindkét esetben két csomag van, és az optimális megoldás egyben nyugtázza ôket a második csomag érkezésekor. Most tegyük fel, hogy $i \leq k$ és a lemma teljesül minden $j<i$-re. Igazoljuk az állítást $i$-re is.

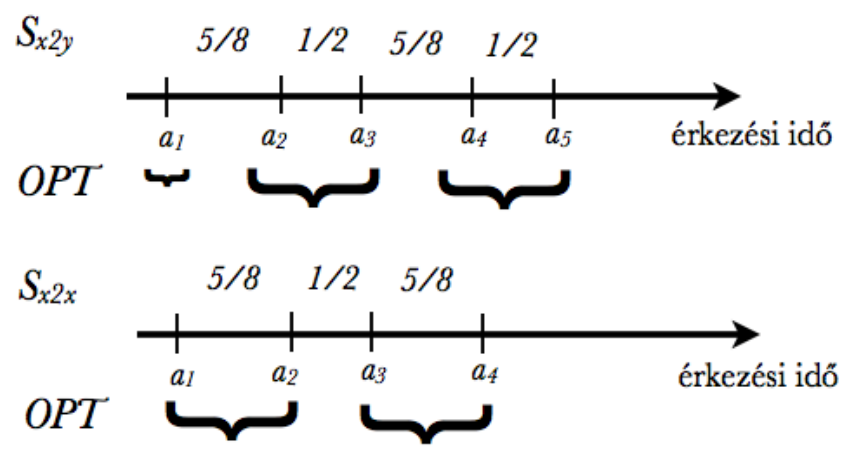

2. ábra. Az $S_{x 2 y}$ és $S_{x 2 x}$ inputok és optimális megoldásai $\gamma=1 / 2$ esetén 
Vegyük elsóként az $S_{x i x}$ sorozatot. Mint a fentiekben észrevettük van olyan optimális megoldás, ami soha nem nyugtáz két csomagnál többet, így két lehetôséget kell megvizsgálnunk az $a_{1}$ csomag nyugtázására vonatkozóan. Ha az $a_{1}$ csomagot az $a_{1}$ időpontban nyugtázzuk, akkor még marad egy $S_{y(i-1) x}$ sorozatunk, amit az indukciós feltevés alapján $i \gamma+(1-\gamma)(i-1) y$ költséggel tudunk nyugtázni. Tehát ebben az esetben a teljes költség $(i+1) \gamma+(1-\gamma)(i-1) y$. Ha az $a_{1}$ csomagot $a_{2}$-vel együtt az $a_{2}=x$ időpontban nyugtázzuk, akkor marad még egy $S_{x(i-1) x}$ sorozatunk, amit az indukciós feltevés alapján $(i-1) \gamma+(1-\gamma)(i-1) x$ költséggel tudunk nyugtázni. Tehát ebben az esetben a teljes költség $i \gamma+i(1-\gamma) x$. Behelyettesítve $x$ és $y$ értékét adódik, hogy a második esetben kapunk kisebb költséget, így az állítást ezen részét igazoltuk $i$-re is.

Teljesen hasonlóan kezelhetó az $S_{y i y}$ sorozat. Ha az $a_{1}$ csomagot az $a_{1}$ időpontban nyugtázzuk, akkor még marad egy $S_{x(i-1) y}$ sorozatunk, amit az indukciós feltevés alapján $i \gamma+(1-\gamma)(i-1) y$ költséggel tudunk nyugtázni. Tehát ebben az esetben a teljes költség $(i+1) \gamma+(1-\gamma)(i-1) y$. Ha az $a_{1}$ csomagot $a_{2}$-vel együtt az $a_{2}=y$ idôpontban nyugtázzuk, akkor marad még egy $S_{y(i-1) y}$ sorozatunk, amit az indukciós feltevés alapján $(i-1) \gamma+(1-\gamma)(i-1) y$ költséggel tudunk nyugtázni. Tehát ebben az esetben a teljes költség $i \gamma+i(1-\gamma) y$. Behelyettesítve $x$ és $y$ értékét adódik, hogy a második esetben kapunk kisebb költséget, így az állítást ezen részét igazoltuk $i$-re is.

Vizsgáljuk most meg az $S_{x i y}$ sorozatot. Ha az $a_{1}$ csomagot az $a_{1}$ időpontban nyugtázzuk, akkor még marad egy $S_{\text {yiy }}$ sorozatunk, aminek az optimális nyugtázási költsége a fentiek alapján $i \gamma+i(1-\gamma) y$. Így a 
teljes költség ebben az esetben $(i+1) \gamma+i(1-\gamma) y$. Ha az $a_{1}$ csomagot $a_{2}$-vel együtt az $a_{2}=x$ idôpontban nyugtázzuk, akkor marad még egy $S_{x(i-1) y}$ sorozatunk, amit az indukciós feltevés alapján $i \gamma+(1-\gamma)(i-1) y$ költséggel tudunk nyugtázni. Tehát ebben az esetben a teljes költség $(i+1) \gamma+(1-\gamma)(i-1) y+x$. Mivel $x>y$ ezért az elsô esetben kapunk kisebb költséget, így az állítást ezen részét is igazoltuk $i$-re is.

Végül vizsgáljuk meg az $S_{y i x}$ sorozatot. Ha az $a_{1}$ csomagot az $a_{1}$ időpontban nyugtázzuk, akkor még marad egy $S_{x i x}$ sorozatunk, aminek az optimális nyugtázási költsége a fentiek alapján $i \gamma+i(1-\gamma) x$. Így a teljes költség ebben az esetben $(i+1) \gamma+i(1-\gamma) x$. Ha az $a_{1}$ csomagot $a_{2}$-vel együtt az $a_{2}=y$ időpontban nyugtázzuk, akkor marad még egy $S_{y(i-1) x}$ sorozatunk, amit az indukciós feltevés alapján $i \gamma+(1-\gamma)(i-1) y$ költséggel tudunk nyugtázni. Tehát ebben az esetben a teljes költség $(i+1) \gamma+i(1-\gamma) y$. Mivel $x>y$ ezért a második esetben kapunk kisebb költséget, így az állítást ezen részét is igazoltuk $i$-re is.

Legyen $S_{x k x}$ az A algoritmus inputjának elsố része, majd várjunk $y$ idôpontig. Tegyük fel, hogy az algoritmus nyugtát küld egy $z \leq y$ idôpontban. Ekkor nyugtázza $a_{1}$ csomagot, majd nyugtáznia kell még az $S_{y(k-1) x}$ sorozatba esó csomagokat is. Ezért az 1. lemából következôen kapjuk, hogy $A\left(S_{x k x}\right) \geq \gamma+(1-\gamma) z+k \gamma+(1-\gamma)(k-1) y$. Tehát

$$
\frac{A\left(S_{x k x}\right)}{O P T\left(S_{x k x}\right)} \geq \frac{(k+1) \gamma+(1-\gamma)(k-1) y}{k \gamma+k(1-\gamma) x}=1+\frac{1}{6 k+1} .
$$

Most tegyük fel, hogy A nem küld nyugtát az y időpont előtt. Ekkor az $y+c$ idôpontban egy további csomag érkezik, így az input $S_{x k y} . \mathrm{Az}$ 
algoritmus észreveszi az új csomagot az y idôpontban. Ha nyugtázza az első csomagot az $x$ idôpont előtt, akkor $A\left(S_{x k y}\right) \geq \gamma+(1-\gamma) y+O P T\left(S_{y k y}\right)$. Így a lemmából következốn az alábbi egyenlőtlenséget kapjuk:

$$
\frac{A\left(S_{x k y}\right)}{O P T\left(S_{x k y}\right)} \geq \frac{(k+1) \gamma+(1-\gamma)(k+1) y}{(k+1) \gamma+(1-\gamma) k y}=1+\frac{1}{3 k+2}
$$

Végül tegyük fel, hogy $A$ nem küld nyugtát $x$ időpont előtt. Ha az első nyugtát az $x$ idôpont után küldi, akkor a teljes költség növekszik, így feltehetjük, hogy az első nyugtát $x$ idôpontban küldi. Ha az algoritmus az elsố két csomagot nyugtázza és a megmaradt rész $S_{x(k-1) y}$, azt kapjuk, hogy $A\left(S_{x k y}\right) \geq \gamma+(1-\gamma) x+O P T\left(S_{x(k-1) y}\right)$. Így a lemmából következóen az alábbi egyenlőtlenséget kapjuk:

$$
\frac{A\left(S_{x k y}\right)}{O P T\left(S_{x k y}\right)} \geq \frac{(k+1) \gamma+(1-\gamma)(x+(k-1) y)}{(k+1) \gamma+(1-\gamma) k y} \geq 1+\frac{1}{6 k^{2}+4 k}
$$

Mivel az összes lehetséges esetet megvizsgáltuk, a tételt bizonyítottuk.

A fenti eredmény azonban nem ad 1-nél jobb alsó korlátot arra az esetre, ha az algoritmus csak kicsi elôretekintéssel rendelkezik. Mutatunk még egy alsó korlátot arra az esetre amikor $c \leq \gamma /(1-\gamma)$ annak a technikának [14] a kiterjesztésével, melyet a 2. fejezetben már olvashattunk.

6. Tétel. Nem létezik olyan c-elôrenézô félig on-line algoritmus a nyugtázási problémára az $f_{\text {sum }}$ modellben, amelynek kisebb a versenyképességi hányadosa, mint $2 \gamma /(c(1-\gamma)+\gamma)$, ha $c \leq \gamma /(1-\gamma)$.

Bizonyítás: Tekintsünk egy tetszőleges on-line algoritmust, jelöljük $A$-val. Elemezzük a következô inputot. Vegyük a csomagok egy hosszú sorozatát 
melyben a csomagok rendre pontosan $c$ időegységgel azután érkeznek, amikor $A$ egy nyugtát küld $\left(t_{j}+c=a_{j+1}\right)$. Ekkor az on-line költség a $2 n+1$ csomagot tartalmazó inputra $A\left(I_{2 n+1}\right)=\gamma(2 n+1)+(1-\gamma) \sum_{i=1}^{2 n+1}\left(t_{i}-a_{i}\right)$. Most tekintsük a következő két off-line algoritmust. ODD csak a páratlan sorszámú csomagot és az utolsó csomagot nyugtázza, EV viszont csak a páros sorszámú csomagokat nyugtázza.

Ezen algoritmusok költségei:

$$
\begin{gathered}
\operatorname{EV}\left(I_{2 n+1}\right)=(n+1) \gamma+(1-\gamma) \sum_{i=1}^{n}\left(a_{2 i+1}-a_{2 i}\right)= \\
(n+1) \gamma+(1-\gamma)\left(n c+\sum_{i=1}^{n}\left(t_{2 i}-a_{2 i}\right)\right)
\end{gathered}
$$

és

$$
\begin{gathered}
\mathrm{ODD}=(n+1) \gamma+(1-\gamma) \sum_{i=1}^{n}\left(a_{2 i}-a_{2 i-1}\right)= \\
(n+1) \gamma+(1-\gamma)\left(n c+\sum_{i=1}^{n}\left(t_{2 i-1}-a_{2 i-1}\right)\right) .
\end{gathered}
$$

Másfelől sem az ODD sem EV nem ér el kisebb költséget mint az optimális off-line költség, így

$$
\begin{gathered}
O P T\left(I_{2 n+1}\right) \leq \min \left\{E V\left(I_{2 n+1}\right), \mathrm{ODD}\left(I_{2 n+1}\right)\right\} \leq \\
\left(E V\left(I_{2 n+1}\right)+O D D\left(I_{2 n+1}\right)\right) / 2 .
\end{gathered}
$$

Ezért

$$
\begin{aligned}
\frac{A\left(I_{2 n+1}\right)}{O P T\left(I_{2 n+1}\right)} & \geq \frac{2\left(\gamma(2 n+1)+(1-\gamma) \sum_{i=1}^{2 n+1}\left(t_{i}-a_{i}\right)\right)}{\gamma(2 n+2)+(1-\gamma)\left(\sum_{i=1}^{2 n}\left(t_{i}-a_{i}\right)+2 n c\right)} \\
& \geq 2-\frac{2 \gamma+4 n c(1-\gamma)}{\gamma(2 n+2)+2 n c(1-\gamma)}
\end{aligned}
$$


Az alsó korlát, amit az $A\left(I_{2 n+1}\right) / O P T\left(I_{2 n+1}\right)$ hányadosra kaptunk, a $2 \gamma /(c(1-\gamma)+\gamma)$ értékhez tart, ha $n$ tart végtelenhez. Ezzel a tételt beláttuk. 


\title{
3. Fejezet
}

\section{Paraméter tanuló algoritmusok a nyugtá- zási problémához}

\begin{abstract}
Általában egy on-line algoritmus hatékonyságát versenyképességi elemzéssel vizsgálják. A versenyképességi hányados a nyugtázási problémára teljesen megoldott [14], az ébresztő algoritmus optimális, azaz a problémában elérhetô legkisebb versenyképességi hányadossal rendelkezik, ez azonban nem jelenti azt, hogy egy másik (esetleg nem optimális versenyképességgel rendelkező algoritmus) ne múködhetne hatékonyabban valós adatokon.
\end{abstract}

Ebben a fejezetben bemutatunk egy új on-line algoritmust és egy új félig on-line algoritmust is a nyugtázási problémára. Az alapötlet mindkét esetben az ébresztô algoritmus továbbfejlesztése. Ezt úgy is fel lehet fogni, mint egy paraméteres algoritmust, ahol a paramétert, úgy választjuk, hogy a versenyképességi hányadost minimalizálja. Az új algoritmus szakaszokban múködik és minden szakaszban megkeresi a paraméter optimális értékét az input utolsó szakaszára. A paraméter ezen új értékét használjuk a következô szakaszban. Teszteket végeztünk az új algoritmus teljesítményének meghatározására és megmutatjuk, hogy az új algoritmus jobb teljesítmény nyújt a teszteken, mint az ébresztő algoritmus. 


\subsection{Jelölések és előzmények}

Most is a korábban definiált $f_{\text {sum }}$ matematikai modellt [14] használjuk. Az ébresztô algoritmus [14] egy kiterjesztését fogjuk használni. Egy ébresztő algoritmus a következóképpen múködik. Az $a_{j}$ csomag érkezésekor beállítunk egy ébresztôt valamilyen $a_{j}+e_{j}$ idôpontra. Ha az $a_{j}+e_{j}$ idôpontig nem érkezik új csomag, akkor az $a_{j}+e_{j}$ idôpontban nyugtát küldünk, egyébként az $a_{j+1}$ érkezésekor átállítjuk az ébresztôt, egy $a_{j+1}+e_{j+1}$ időpontra.

Az 1. és 4. prepozíciókból következik, hogy nem létezik a problémára kisebb versenyképességi hányadosú on-line algoritmus ebben a modellben, de ennek ellenére egy új algoritmus jobb lehet átlagos esetben. Egy algoritmusra $A$ és inputra $I$ egy $A(I)$ alakú kifejezés az $A$ algoritmus költségét jelenti $I$ inputon az $f_{\text {sum }}$ célfüggvényen.

\subsection{On-line paraméter tanuló algoritmus}

Most bemutatjuk a paraméter tanuló algoritmust. Az algoritmus szakaszokban múködik és az ébresztô algoritmust használja a csomagok nyugtázására. Elôször definiáljuk az ébresztô algoritmus egy verzióját melyet használni fogunk, az Alarm $p$ algoritmust, mely egy pozitív $p$ para-

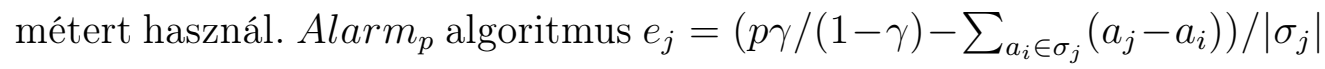
értéket használja minden $j$-hez. Ez az $e_{j}$ érték azt jelenti, hogy ha nem érkezik új csomag $a_{j}+e_{j}$ idôpontig, az algoritmus $a_{j}+e_{j}$ idôpontban 
nyugtázza az összes még nyugtázatlan csomagot. A késedelmi költség $\left.\sum_{a_{i} \in \sigma_{j}}\left(a_{j}-a_{i}\right)\right)+\left|\sigma_{j}\right| \cdot e_{j}=p \cdot \gamma /(1-\gamma)$. Meg kell jegyeznünk, hogy $A \operatorname{larm}_{1}$ az elôzốkben már tárgyalt 2-versenyképes ébresztő algoritmus [14].

Az új paraméter tanuló algoritmus ezen $p$ paraméter tanulásán alapszik, továbbá használja az $r$ és $q$ paramétereket, amelyek a tanulási fázis hosszát határozzák meg. Az algoritmus a következóképpen múködik.

\section{LearnAlarm(r,q) algoritmus}

- 1. szakasz Használjuk az Alarm 1 algoritmust az elsô $r$ csomag nyugtázásához. Ugrás a 2. szakaszra.

- $j \cdot \operatorname{szakasz}(j>1)$

- Jelölje $I_{j}$ az inputot, ami az utolsó $r \cdot q$ csomag. Ha kevesebb csomag érkezett, akkor $I_{j}$ mindet tartalmazza.

- A SimpleOpt algoritmust használjuk a $p$ azon értékének meghatározására, mely minimalizálja az Alarm $_{p}$ algoritmus költségét az $I_{j}$ inputon. Jelölje ezt az értéket $p^{*}$.

- Az Alarm $_{p^{*}}$ algoritmust használjuk a következô $r$ csomag nyugtázására majd folytassuk a $j+1$. szakaszon. 


\subsection{Az optimális $p$ érték meghatározása az $\operatorname{Alarm}_{p}$ al- goritmushoz}

A következő lemma fontos szerepet játszik a $p$ paraméter optimális értékét meghatározó algoritmus kifejlesztésében.

2. Lemma. A p optimális értéke olyan, hogy a nyugtázás idópontja pontosan valamely csomag beérkezési idôpontjával egyenló.

Bizonyítás: Tekintsünk a csomagok egy tetszóleges sorozatát, jelöljük I-vel és egy $p$ értéket, amelyik nem teljesíti a lemma által definiált tulajdonságot. Megmutatjuk, hogy ez nem optimális érték $I$-hez. Jelölje $k$ az $A_{l a r m}$ algoritmus által küldött nyugták számát. Az Alarm, definíciójából következik, hogy minden nyugta teljes késedelme $p \gamma /(1-\gamma)$, ezért $\operatorname{Alarm}_{p}(I)=k \gamma+(1-\gamma) k p \gamma /(1-\gamma)=k \gamma(1+p)$. Mivel feltevésünk szerint Alarm $_{p}$ nem pontosan egy csomag megérkezésekor küldi a nyugtát, ezért létezik egy $\varepsilon>0$, amire egy másik algoritmus a $p$ helyett egy $p-\varepsilon$ paramétert használva ugyanazokat a csomagokat nyugtázza mint Alarm $_{p}$, de korábban. Ez azt jelentené, hogy az Alarm $_{p-\varepsilon}$ ugyanúgy $k$ nyugtát használná továbbá azt is, hogy $\operatorname{Alarm}_{p-\varepsilon}(I)=k \gamma(1+p-\varepsilon)$ ami azt mutatja, hogy ekkor $p$ nem optimális választás.

Emiatt a következô algoritmust használhatjuk a $p$ paraméter optimális értékének meghatározására. Az algoritmus csak azokat az értékeket vizsgálja, melyek a lemma által támasztott kritériumnak megfelelnek. 


\section{A SimpleOptAlarm Algoritmus}

- Inicializálás: Legyen $p^{*}=1$ és $Z=\infty$

- Keresés: Minden $1 \leq i<j \leq n$-re

- Legyen $s:=\sum_{k=i}^{j}\left(a_{j}-a_{i}\right)$, és $p:=(1-\gamma) s / \gamma$.

- Futtassuk p-re Alarm $_{p}$-t az inputon és határozzuk meg a nyugtát számát $(k)$

- Ha $k \gamma(1+p)<Z$, akkor $p^{*}:=p$ és $Z:=k \gamma(1+p)$

- Return $p^{*}$

A keresés $\Theta\left(n^{2}\right)$ iterációt igényel és minden iterációban a második lépés futási ideje $\Theta(n)$, így az algoritmus futási ideje $\Theta\left(n^{3}\right)$.

\subsection{Az Learn Alarm $(r, q)$ algoritmus hatékonysági vizs- gálata}

Az új paraméter tanuló algorimusunkat teszteknek vetettük alá, hogy a hatékonyságát értékeljük. A tesztek végrehajtásához valós adatokat és véletlen generált inputot is felhasználtunk. Hogy jobban megértsük az egyes paraméterek szerepét és hatásait az adatokon több különböző paraméter beállítással is futtattuk az algoritmust. Az $A 1, A 2, \ldots, A 6$ algoritmusok a $q=10$ és rendre a $r=100,200,500,1000,2000,4000$ értékeket használták a tesztek futtatása során. A $B 1, B 2, \ldots, B 6, C 1, \ldots, C 6, D 1, \ldots, D 6$, $E 1, \ldots, E 6$ algoritmusok rendre a $q=25,50,75,100$ és $r=100,200,500$, 1000, 2000, 4000 értékekkel futottak. 


\subsubsection{Tesztek valós adatokon}

Két különböző webszerver forgalmát vizsgáltuk: a http://www.sziszszi.hut, egy némileg kisebb forgalmú egy középiskola webszerverének forgalmát, melyre a tesztekben Szerver1-ként hivatkozunk, és egy nagyobb forgalmú szervert, mely több mint 30 általános- és középiskola intézményi adminisztrációját és elektronikus naplóját szolgálja ki, ezt Szerver2-vel jelöltük. Mindkét szerveren naplóztuk egy-egy adatbázisba azon események idôpontjait, amihez adatcsomag küldése tartozott. Ezeket az adatokat használtuk fel a tesztek inputjaként. Mindkét adatbázisból 3 különböző méretú részinputot használtunk: small (10,000) medium $(100,000)$ large (500,000), melyeket rendre $S, M$ és $L$ jelöl. Mindegyik méretból 10-10 tesztesetet generáltunk az adatbázisok különbözô részeiból. Az inputok letölthetők a

www.inf.u-szeged.hu/ cimreh/dataack/acknowltest.zip webcímről.

Az algoritmusokat 3 különböző célfüggvénnyel teszteltük, 0.25, 0.5 és $0.75 \gamma$ értékekkel. Mindegyik inputra egy dinamikus programozás elvú algoritmus segítségével [14] meghatároztuk az optimális off-line megoldást, ezt jelölje OPT. Tehát minden inputon 31 on-line algoritmust futtattunk:

$$
\text { Alarm }, A 1, \ldots, A 6, B 1, \ldots, B 6, \ldots, E 1, \ldots, E 6
$$

algoritmusokat. A egyes on-line algoritmusok költségeinek átlagát, az optimális off-line költségek átlagát és ezek arányait az 1. számú függelékben található táblázat tartalmazza. A 3. és 4. ábra az $A L G / O P T$ értékek átlagát ábrázolja az egyes szerverek adataival néhány algoritmushoz. 


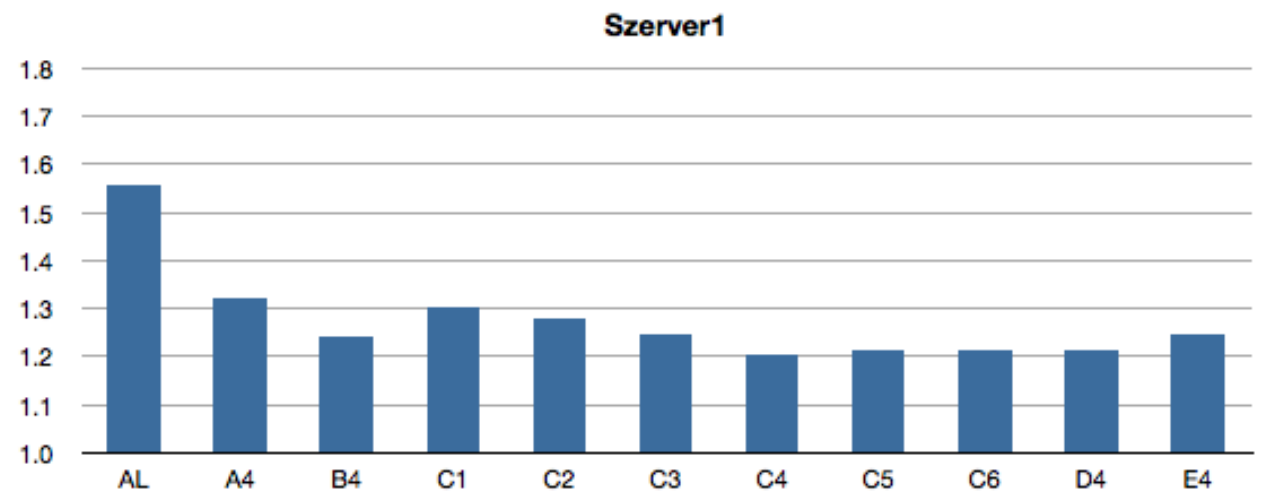

3. ábra. Néhány algoritmus teljesítménye a Szerver1-en

A $C 1, C 2, \ldots, C 6$ algoritmusokat azért választottuk ki, hogy az $r$ paraméter hatását be tudjuk mutatni, az $A, B, D, E$ algoritmus osztályok legjobb eredményei azt mutatják be, hogy a $q$ paraméter hogyan befolyásolja az algoritmus múködését, és hogyan kell a megfelelő q értéket a problémához optimálisan beállítani. $\operatorname{Alarm}(A L)$ lényegesen rosszabb értéke a diagramon jól mutatja a paraméter tanuló algoritmus gyakorlati hasznát.

\subsubsection{Tesztek végrehajtása generált adatokon}

A valós adatokon végrehajtott tesztek mellett véletlen-generált inputokon is teszteltük az algoritmusokat. Két tesztesetet vizsgáltunk. Az elsố esetben egyenletes eloszlású érkezési idóket, míg a másodikban exponenciális eloszlású inputot generáltunk. Ezt ez eloszlást egy homogén Poisson-folyamat eredményezi, mely gyakran előforduló telekommunikációs jelenség. Itt is minden inputon 31 on-line algoritmust futtattunk, az Alarm, $A 1, \ldots, A 6, B 1, \ldots, B 6, \ldots, E 1, \ldots, E 6$ algoritmusokat. A egyes 


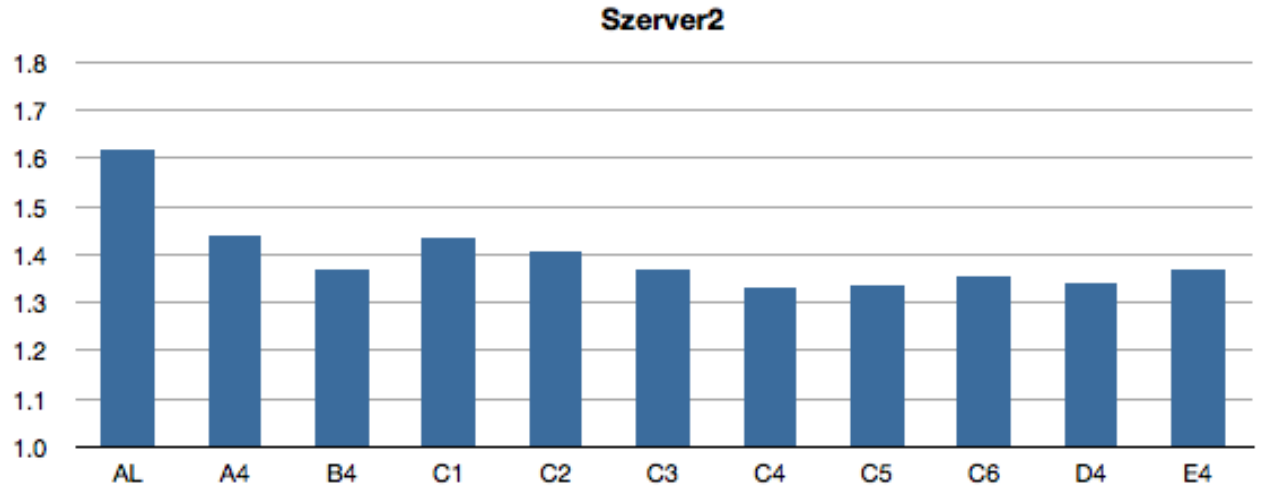

4. ábra. Néhány algoritmus teljesítménye a Szerver2-ôn

on-line algoritmusok költségeinek átlagát, az optimális off-line költségek átlagát és ezek arányait a ... számú függelékben található táblázat tartalmazza.

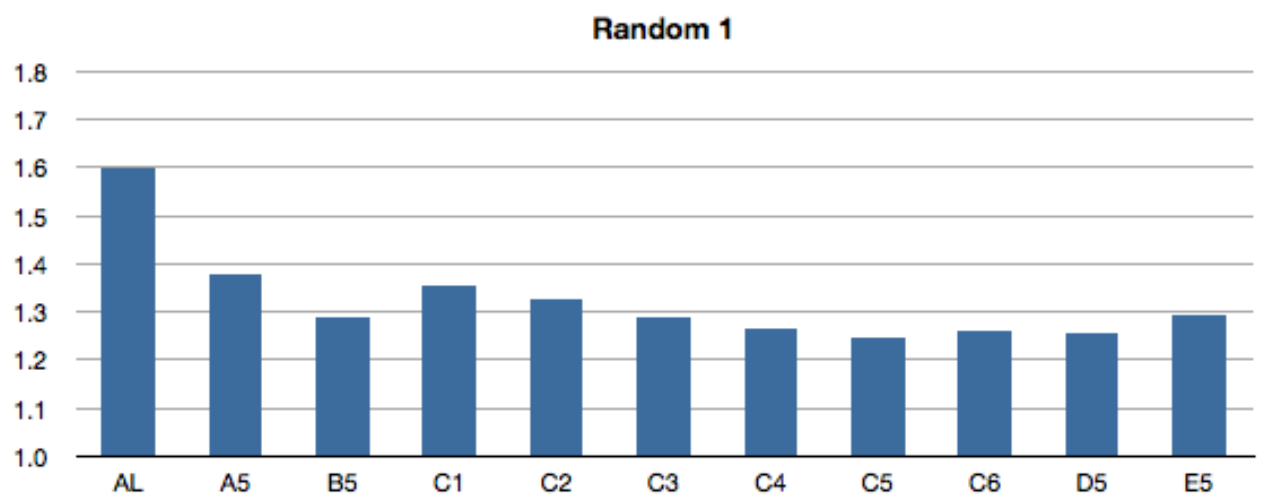

5. ábra. Néhány algoritmus teljesítménye egyenletes eloszlású adatokon

Az 5. és 6. ábrán néhány algoritmus teszteredményeit láthatjuk a valós adatoknál ismertetett szempontok alapján. A véletlen-generált adatokon futtatott tesztek eredményeinek eredményeit az 1. számú függelékben 


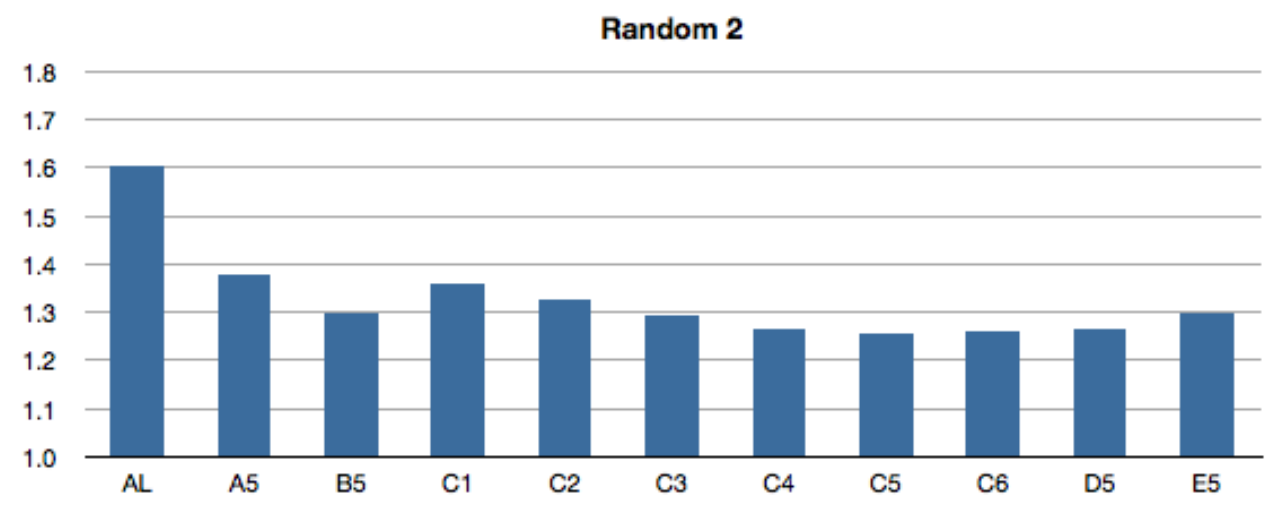

6. ábra. Néhány algoritmus teljesítménye exponenciális eloszlású adatokon

található táblázat tartalmazza.

\subsubsection{Következtetések}

A fenti eredmények alapján a következô következtetéseket vonhatjuk le:

- A legfontosabb megfigyelésünk, hogy a tesztek eredményei tisztán mutatják, hogy a paraméter tanulás jelentôs hatékonyságjavulást eredményez az Alarm algoritmus múködésében.

- A teszteredmények alapján az is jól látható, hogy az új algoritmus igen érzékeny a paraméterek beállításaira. Egy pontos paraméterbeállítás tovább csökkenti az $A L G / O P T$ hányadost. Az is jól látszik, hogy a paraméterek optimális beállítása az input függvénye, de néhány általános következtetést levonhatunk. Úgy túnik, hogy egy közepes hosszúságú tanulási szakasz jobb eredményt ad, mint egy 
rövid, vagy egy hosszú. Ami a vizsgált szakaszok hosszát illeti $(r$ paraméter), az látszik, hogy 1000 - 2000-ig növelve azt jelentős javulással számolhatunk, de a további növelés nem hoz szignifikáns javulást az algoritmus hatékonyságában. A véletlen-generált teszteken az $r=2000$, míg valós adatokon az $r=1000$ beállítás adott jobb eredményeket.

- Miután összehasonlítjuk a különböző tesztesetek eredményeit azt a következtetést is levonhatjuk, hogy az algoritmusok hasonló viselkedést mutatnak. A Szerver2-ôn a javulás valamivel jobb volt, mint a többi esetben.

\subsection{Félig on-line paraméter tanuló algoritmus}

Ebben a fejezetben a nyugtázási probléma idő-előretekintő változatát [27] vizsgáljuk. A 2. fejezetben már megmutattuk, hogy a nyugtázási probléma idô-előretekintố modelljében definiált Ébresztô algoritmus kiterjesztése bármely $c$-re sem jobb mint 2-versenyképes. Most definiáljuk egy paraméter tanuló változatát ennek az algoritmusnak. Analizáljuk az algoritmust az elózó fejezetben ismertetett valós adatokon [28], továbbá véletlen-generált adatokon is. Az eredmények megmutatják, hogy az átlagos esetben az idő-elốretekintő tulajdonság lényegesen jobb eredményeket produkál, mint az Ébresztố algoritmus on-line változata, és az eredményeket a paraméter-tanulás ötlete tovább javítja. 
A második fejezetben részletesen bemutatott félig on-line $c$ idő-előretekintô modellt fogjuk alkalmazni, ahol a döntéshozó ismeri a $t$ idôpontban már megérkezett csomagok érkezési időpontját, továbbá a azon csomagok érkezési idôpontját is amik a $(t, t+c]$ intervallumban érkeznek.

Most kiterjesztjük a TLA algoritmust egy paraméter tanuló algoritmussá a fejezetben korábban tárgyalt módszerrel.

Paraméter tanuló TLA algoritmus: Az algoritmus szakaszokban múködik. Minden szakasz a TLA algoritmust használja a csomagok nyugtázására. Elôször definiáljuk az ébresztô algoritmus egy verzióját melyet használni fogunk, az $T L A_{p}$ algoritmust, mely egy pozitív $p$ paramétert használ. $T L A_{p}$ algoritmus $e_{j}=\left(p \gamma /(1-\gamma)-\sum_{a_{i} \in \sigma_{j}}\left(a_{j}-a_{i}\right)\right) /\left|\sigma_{j}\right|$ értéket használja minden $j$-hez. Ez az $e_{j}$ érték azt jelenti, hogy ha nem érkezik új csomag $a_{j}+e_{j}$ időpontig, az algoritmus $a_{j}+e_{j}$ idôpontbn nyugtázza az összes még nyugtázatlan csomagot. A késedelmi költség $\left.\sum_{a_{i} \in \sigma_{j}}\left(a_{j}-a_{i}\right)\right)+\left|\sigma_{j}\right| \cdot e_{j}=p \cdot \gamma /(1-\gamma)$. Meg kell jegyeznünk, hogy $T L A_{1}$ algoritmus 2-versenyképes [28].

Az új paraméter tanuló algoritmus a paraméter tanulásán alapszik, és az $r$ és $q$ paramétereket használja, amik a tanulási fázis hosszát határozzák meg. Az algoritmus a következőképpen múködik. 


\section{LearnTLA(r,q) algoritmus}

- 1. szakasz Használjuk az $T L A_{1}$ algoritmust az elsô $r$ csomag nyugtázásához. Ugrás a 2. szakaszra.

- $j . \operatorname{szakasz}(j>1)$

- Jelölje $I_{j}$ az inputot, ami az utolsó $r \cdot q$ csomag. Ha kevesebb csomag érkezett, akkor $I_{j}$ mindet tartalmazza.

- A SimpleOpt algoritmust használjuk a $p$ azon értékének meghatározására, mely minimalizálja az $T L A_{p}$ algoritmus költségét az $I_{j}$ inputon. Jelölje ezt az értéket $p^{*}$.

- Az Alarm $p^{*}$ algoritmust használjuk a következô $r$ csomag nyugtázására majd folytassuk a $j+1$. szakaszon.

A következő $\Theta\left(n^{3}\right)$ futási idejû algoritmus meghatározza $p$ optimális értékét.

\section{A SimpleOptTLA Algoritmus}

- Inicializálás: Legyen $p^{*}=1$ és $Z=\infty$

- Keresés: Minden $1 \leq i<j \leq n$-re

- Legyen $s:=\sum_{k=i}^{j}\left(a_{j}-a_{i}\right)$, és $p:=(1-\gamma) s / \gamma$.

- Futtassuk $p$-re $T L A_{p}$-t az inputon és határozzuk meg a nyugtát számát $(k)$

- Ha $k \gamma(1+p)<Z$, akkor $p^{*}:=p$ és $Z:=k \gamma(1+p)$

- Return $p^{*}$ 


\subsection{Az algoritmusok értékelése}

Az új paraméter tanuló algorimusunkat teszteknek vetettük alá, hogy a hatékonyságát értékeljük. A tesztek végrehajtásához itt is valós adatokat és véletlen generált inputot használtunk. Minden inputra futtattuk az optimális off-line megoldást a dinamikus programozás módszerével meghatározó [14] algoritmust, ezen a megoldáson felvett célfüggvény értéket jelöltük OPT-tal, továbbá minden inputra futtattuk a TLA algoritmust is. Ezen kívưl számos különböző paraméter beállítással futtattuk az új algoritmust is. Az $A 1, A 2, A 3$ algoritmusok a $q=25$ és rendre a $r=200,2000,4000$ értékeket használták a tesztek futtatása során. A $B 1, B 2, B 3, C 1, C 3, C 3$, és $D 1, D 2, D 3$ algoritmusok rendre a $q=50,75,100$ és $r=200,2000,4000$ értékekkel futottak. Az előretekintô algoritmusokat minden teszt bemenetnél két különböző előretekintő értéken vizsgáltuk, $c=0.2$ és $c=0.8$ értékekkel.

\subsubsection{A valós tesztadatok}

Itt is a szakoktatas.hu webszerver forgalmi eseményeinek egy adatbázisba rögzített (naplózott) időpontjait használtuk a tesztek futtatása során. Az adatbázisból 3 különböző méretű részinputot használtunk fel a tesztekhez az algoritmusok inputjaként: kis méretú input - small (10,000 adat), közepes méretú - medium (100,000 adat) és nagy méretú input - large (500,000 adat), melyeket rendre $S, M$ és $L$ jelöl. Minden mérethez 10 különböző inputot konstruáltunk. Az algoritmusokat 3 különbözô célfüggvény mellett analizáltuk, 0.25, 0.5 és 0.75-ös $\gamma$ értékek mellett. A 
1. táblázat. teszt eredmények a $c=0.2$ értékhez

\begin{tabular}{|c|c|c|c|c|}
\hline & OPT & AL & TLA & B2 \\
\hline $\mathrm{S}(0,25)$ & 2114 & 3798 & 2748 & 2575 \\
\hline $\mathrm{S}(0,5)$ & 4271 & 6517 & 5566 & 5215 \\
\hline $\mathrm{S}(0,75)$ & 5744 & 8187 & 7467 & 6993 \\
\hline $\mathrm{M}(0,25)$ & 21735 & 38026 & 28212 & 26501 \\
\hline $\mathrm{M}(0,5)$ & 43272 & 64534 & 56253 & 52791 \\
\hline $\mathrm{M}(0,75)$ & 58552 & 82466 & 75883 & 71357 \\
\hline $\mathrm{L}(0,25)$ & 107539 & 191773 & 139263 & 130982 \\
\hline $\mathrm{L}(0,5)$ & 224571 & 323450 & 291268 & 273967 \\
\hline $\mathrm{L}(0,75)$ & 298716 & 412946 & 386240 & 363448 \\
\hline
\end{tabular}

teszteredmények átlagait az 1. és 2. táblázatban összesítettük, ahol az optimális off-line megoldás, az ébresztô algoritmus, a TLA algoritmus és a legjobb paraméter tanuló algoritmus eredményei szerepelnek. Kiszámoltuk az egyes algoritmusok optimális off-line költséghez viszonyított arányát is. Az ébresztố algoritmus esetében ez az arány 1.556, a TLA algoritmus esetében pedig rendre 1.298 és 1.211 a $c=0.2$ és $c=0.8$ értékekre. A paraméter tanuló algoritmusokra az arányt a paraméter beállítások függvényében a 3 . és 4 . táblázat mutatja.

\subsubsection{Generált tesztadatok}

A valós adatok használata mellett véletlen generált bemenetekkel is teszteltük az algoritmusokat. Két különböző esetet vizsgáltunk, az elsô esetben egyenletes eloszlású érkezési időket, a másodikban exponenciális eloszlású érkezési időket generáltunk. Itt is meghatároztuk az egyes algoritmusok és az optimális off-line megoldás költségének arányát. Az 
2. táblázat. teszt eredmények a $c=0.8$ értékhez

\begin{tabular}{|c|c|c|c|c|}
\hline & OPT & AL & TLA & B2 \\
\hline $\mathrm{S}(0,25)$ & 2114 & 3798 & 2555 & 2429 \\
\hline $\mathrm{S}(0,5)$ & 4271 & 6517 & 5186 & 4920 \\
\hline $\mathrm{S}(0,75)$ & 5744 & 8187 & 6967 & 6597 \\
\hline $\mathrm{M}(0,25)$ & 21735 & 38026 & 26341 & 25001 \\
\hline $\mathrm{M}(0,5)$ & 43272 & 64534 & 52488 & 49803 \\
\hline $\mathrm{M}(0,75)$ & 58552 & 82466 & 71011 & 67335 \\
\hline $\mathrm{L}(0,25)$ & 107539 & 191773 & 129390 & 123873 \\
\hline $\mathrm{L}(0,5)$ & 224571 & 323450 & 272404 & 258892 \\
\hline $\mathrm{L}(0,75)$ & 298716 & 412946 & 361167 & 342960 \\
\hline
\end{tabular}

3. táblázat. ALG/OPT eredmények a $c=0.2$ értékhez valós adatokon

\begin{tabular}{|c|c|c|c|c|}
\hline & $\mathrm{A}$ & $\mathrm{B}$ & $\mathrm{C}$ & $\mathrm{D}$ \\
\hline 1 & 1.230 & 1.220 & 1.221 & 1.225 \\
\hline 2 & 1.221 & 1.219 & 1.219 & 1.222 \\
\hline 3 & 1.223 & 1.219 & 1.220 & 1.223 \\
\hline
\end{tabular}

4. táblázat. ALG/OPT eredmények a $c=0.8$ értékhez valós adatokon

\begin{tabular}{|c|c|c|c|c|}
\hline & $\mathrm{A}$ & $\mathrm{B}$ & $\mathrm{C}$ & $\mathrm{D}$ \\
\hline 1 & 1.168 & 1.151 & 1.152 & 1.155 \\
\hline 2 & 1.163 & 1.150 & 1.150 & 1.153 \\
\hline 3 & 1.165 & 1.150 & 1.151 & 1.54 \\
\hline
\end{tabular}

egyenletes eloszlású adatokon az ébresztô algoritmusnál átlagos arány 1.601, a TLA algoritmusnál 1.276 és 1.183 a $c=0.2$ és $c=0.8$ értékekre. A paramétertanuló algoritmusokra az arányt a paraméter beállítások függvényében az 5. és 6 . táblázat mutatja.

Az tesztek az exponenciális eloszlású adatokon az ébresztő algoritmus 
5. táblázat. ALG/OPT eredmények a $c=0.2$ értékhez, egyenletes eloszlású inputon

\begin{tabular}{|c|c|c|c|c|}
\hline & $\mathrm{A}$ & $\mathrm{B}$ & $\mathrm{C}$ & $\mathrm{D}$ \\
\hline 1 & 1.212 & 1.197 & 1.198 & 1.201 \\
\hline 2 & 1.198 & 1.196 & 1.196 & 1.199 \\
\hline 3 & 1.199 & 1.196 & 1.196 & 1.1 .200 \\
\hline
\end{tabular}

6. táblázat. ALG/OPT eredmények a $c=0.8$ értékhez, egyenletes eloszlású inputon

\begin{tabular}{|c|c|c|c|c|}
\hline & $\mathrm{A}$ & $\mathrm{B}$ & $\mathrm{C}$ & $\mathrm{D}$ \\
\hline 1 & 1.138 & 1.130 & 1.130 & 1.133 \\
\hline 2 & 1.130 & 1.128 & 1.128 & 1.131 \\
\hline 3 & 1.132 & 1.129 & 1.129 & 1.132 \\
\hline
\end{tabular}

7. táblázat. ALG/OPT eredmények a $c=0.2$ értékhez, exponenciális eloszlású inputon

\begin{tabular}{|c|c|c|c|c|}
\hline & $\mathrm{A}$ & $\mathrm{B}$ & $\mathrm{C}$ & $\mathrm{D}$ \\
\hline 1 & 1.229 & 1.220 & 1.220 & 1.224 \\
\hline 2 & 1.219 & 1.217 & 1.217 & 1.220 \\
\hline 3 & 1.222 & 1.220 & 1.219 & 1.223 \\
\hline
\end{tabular}

8. táblázat. ALG/OPT eredmények a $c=0.8$ értékhez, exponenciális eloszlású inputon

\begin{tabular}{|c|c|c|c|c|}
\hline & $\mathrm{A}$ & $\mathrm{B}$ & $\mathrm{C}$ & $\mathrm{D}$ \\
\hline 1 & 1.160 & 1.151 & 1.151 & 1.155 \\
\hline 2 & 1.150 & 1.147 & 1.147 & 1.149 \\
\hline 3 & 1.153 & 1.150 & 1.150 & 1.154 \\
\hline
\end{tabular}

esetében 1.604, a TLA algoritmus esetében rendre 1.288 és 1.1214 arányt eredményeztek a $c=0.2$ és $c=0.8$ értékekre. Az exponenciális eloszlású inputokon a paraméter tanuló algoritmusokhoz kapott arányokat a 7. és 8. táblázat mutatja a paraméter beállítások függvényében. 


\subsubsection{Következtetések}

Ebben a fejezetben az on-line nyugtázási probléma idő-előretekintő algoritmusainak egy empírikus analízisét mutattunk be. Összehasonlítottuk az ébresztő algoritmust és annak idő-előretekintő változatát valamint a paraméter tanuló on-line algoritmusunkat az optimális off-line algoritmus megoldásának eredményével. Az eredmények alapján az alábbi következtetéseket vonhatjuk le:

- A vizsgálatok alapján a fô megfigyelésünk, hogy a versenyképességi analízis eredményével ellentétben mind a paraméter tanulás, mind az előretekintô tulajdonság jelentôs javulást eredményez a az ébresztő algoritmus átlagos teljesítményében. A $c=0.2$ előretekintő értéknél az ALG/OPT hányados 17\%-ot csökkent az előretekintés hatására, és további $7 \%$-ot a paraméter tanulás ötletét használva. A $c=$ 0.8 esetben az elöretekintés hatására $22 \%$-ot, a paraméter tanulás hatására további 5\%-ot javult a hatékonyság.

- A teszteredményekből az is jól látszik, hogy az különbözô inputok nem befolyásolják jelentősen az algoritmusok hatékonyságát, bár meg kell jegyeznünk, hogy egyenletes eloszlás mellett enyhén jobb eredményeket kapunk.

- Végül azt is észrevehetjük, hogy a paraméter tanuló algoritmus az idô-elôretekintő esetben nem érzékeny annyira a különbözô paraméter beállításokra, mint az on-line esetben, minden beállítás mellett hasonló eredményeket kapunk. 


\section{Fejezet}

\section{Visszautasításos on-line ütemezés}

Ebben a fejezetben egy új algoritmust mutatunk be és elemzünk az on-line visszautasításos ütemezés problémájának megoldására, azonos gépek alkalmazása esetén.

Az ütemezési feladatokban munkák végrehajtását kell megszerveznünk. Az általános modellben egy gyártási folyamat során a munkadarabokon több különbözô múveletet kell elvégezni. Ehhez meg kell határozni az egyes múveleteket végrehajtó gépeket és az időintervallumokat, melyekben az egyes múveletek végrehajtódnak.

A továbbiakban azt az egyszerúbb modellt vizsgáljuk, melyben minden munka egyetlen múveletből áll, tehát a feladatunk az, hogy a munkához, amelynek ismerjük a végrehajtási idejét hozzárendeljük azt a gépet, amelyen a munkát végrehajtjuk, továbbá a végrehajtás kezdeti és befejezési idôpontját. A két idôpont különbsége a végrehajtási idő. Azzal a modellel foglalkozunk, amikor a végrehajtás ideje minden gépen ugyanannyi, tehát párhuzamos azonos gépekról beszélünk. Az on-line modellben a munkák egy listáról érkeznek. Amikor egy munkát megkapunk a listáról, akkor ismerjük meg a szükséges végrehajtási időt. Ezt követően ütemeznünk kell a munkát, hozzárendelve a kezdési és befejezési idôt, amelyet késóbb már nem változtathatunk meg, és csak ezt követően kapjuk meg a listáról a következố munkát. 
A visszautasításos ütemezés problémájában [4] az algoritmusnak lehetôsége van az egyes munkákat visszautasítani. A munkák jellemzője a végrehajtási idő és a visszautasítás büntetése. Célunk itt az elfogadott munkák befejezési idejének és a visszautasítás büntetéseinek összegét minimalizálni. Létezik egy 2.618-versenyképes algoritmus az on-line esetre tetszôleges számú géphez. Ezt az algoritmust RTP algoritmusnak (Reject Total Penalty) nevezik, és az egyik alapötlete az, hogy minden munkára hasonlítsuk össze a büntetést és a terhelést (végrehajtási idő osztva a gépek számával), majd utasítsuk el azokat a munkákat, melyekre a büntetés kisebb mint a terhelés. Ez az alapötlet még csak a mohó algoritmust adja, ami akkor hoz rossz döntést, ha a gépek száma nagy, mert ez lehetôvé teszi, hogy úgy túnjön, hogy egy nagy munka kis terhelést jelent. Az RTP algoritmus ezeket a munkákat sokkal óvatosabban kezeli. Ismert továbbá 1.618-versenyképes algoritmus is a 2 gépes ütemezéshez [4] és ezzel egyezô alsó határ is ismert. Az off-line esetet megoldhatjuk egy dinamikus programozáson alapuló teljesen polinomiális approximációs sémával, ha a gépek számát konstansnak tekintjük, és egy polinomiális idejû approximációs sémával, ha a gépek száma az input része [4]. Az on-line visszautasításos ütemezés megszakítható munkákkal modellt a [36] cikkben vizsgálták. A probléma további általánosítása, amikor a gépek használatának is van költsége [11, 30] és az algoritmusnak ezt ki kell fizetnie ha egy gépet használni szeretne.

Fontosnak tartjuk megjegyezni, hogy az ütemezési problémát követően egyéb on-line visszautasításos modelleket is vizsgáltak. Az on-line visszautasításos ládapakolást, ahol a költség a használt ládák számának 
és a visszautasított tárgyak büntetésének az összege a [12] és [19] cikkekben vizsgálták. Az on-line visszautasításos gráfszínezést tárgyalja a [18] cikk. Az on-line visszautasításos lapozás a [20] cikkben vizsgálják, a visszautasításos $k$-szerver problémát pedig a [6] cikkben.

A feladat egy általánosítása az az ütemezési modell, ahol két géphalmaz van és minden munkának két végrehajtási ideje, attól függően, hogy melyik géphalmaz gépén hajtjuk végre. A célfüggvény a gépcsoportokon vett maximális befejezési idők összege. Ha az egyik csoport egyetlen gépból áll, akkor a visszautasításos ütemezési modellt kapjuk. Ezt a modellt a [24, 25] cikkekben vizsgálták, ahol elemezték az RTP algoritmus egy kiterjesztését és megadtak egy teljesen polinomiális approximációs sémát az off-line problémára.

Ebben a fejezetben bemutatunk néhány már ismert eredményt a visszautasításos on-line ütemezés területérôl, majd bemutatjuk az új paraméter tanuló algoritmusunkat is. Az algoritmusokat hatékonysági vizsgálatnak vetjük alá valós és generált adatokból készített input szekvenciákon végzett tesztek alapján, majd kiértékeltük a kapott eredményeket.

\subsection{Jelölések és elôzmények}

A problémában $m$ azonos gépet használunk. Minden $j$ munkának van egy $p_{j}$ végrehajtási ideje és egy büntetése $w_{j}$. A munkák tetszóleges $J$ sorozatára $A$ algoritmus által választott ütemezés költsége $A(J)$. Az on-line ütemezési algoritmust eljárásként fogjuk használni. Számos az on-line ütemezési probléma megoldására kifejlesztett algoritmus [37] használ mohó 
stratégiát a probléma megoldására [37] úgy, hogy az algoritmus mindig mohón ütemezi az érkezô munkát az elsô szabad gépre. A visszautasítás lehetőségét is felhasználva kézenfekvő az ötlet, hogy utasítsuk el a munkát, ha a visszautasítás büntetése kisebb, mint a munka végrehajtása esetén járó haszon. Az alábbi mohó algoritmus egy (nem optimális) megoldást nyújt a problémára.

\section{A Greedy algoritmus}

Ha a $j$ munkára $w_{j} \leq p_{j} / m$, utasítsuk el, egyébként ütemezzük a munkát arra a gépre, ahol a legkisebb az eddig odarendelt munkák végrehajtási idejének összege.

Sajnos a Greedy algoritmus mohó választása némely esetben nem jó. Ha csak egyetlen nagy végrehajtási idedú $M$ munka érkezik és a visszautasításának büntetése $M / m+\varepsilon$, a mohó választás elfogadja és beütemezi a munkát. Így az algoritmus nem lehet $m$-versenyképesnél jobb, tehát a versenyképességi hányados nem konstans.

Az RTP algoritmus [4] ellenben konstans versenyképességi hányadossal rendelkezik. Ez a Greedy algoritmusnak egy kifinomultabb változata, ami szintén visszautasítja azokat a munkákat (amikre $w_{j} \leq p_{j} / m$ ), de a visszautasított munkákat összegyưjti egy $R$ halmazba, és bizonyos nagy munkákat akkor is visszautasít, ha $w_{j}>p_{j} / m$. 


\section{Algorithm RTP $(\alpha)$}

- 1. Inicializáció. Legyen $R:=\emptyset$.

- 2. Egy új $j$ munka érkezésekor

- (i) Ha $w_{j} \leq \frac{p_{j}}{m}$, visszautasítjuk a munkát.

- (ii) Legyen $r=\sum_{i \in R} w_{i}+w_{j}$. Ha $r \leq \alpha \cdot p_{j}$, visszautasítjuk a $j$ munkát és $R:=R \cup\{j\}$.

- (iii) Egyébként elfogadjuk j-t és ütemezzük a munkát arra a gépre, ahol a legkisebb az eddig odarendelt munkák végrehajtási idejének összege.

Az RTP algoritmus versenyképességi hányadosáról és a felső korlátról [4] a következók állíthatók.

5. Prepozíció. Az RTP az $\alpha=(\sqrt{ }(5)-1) / 2$ paraméterrel $(3+\sqrt{(5)}) / 2$ versenyképes.

6. Prepozíció. Nem létezik olyan $\beta$-versenyképes on-line algoritmus tetszóleges $m$-re, ahol $\beta<(3+\sqrt{5}) / 2$

\subsection{Paraméter tanuló algoritmus}

A prepozíciók alapján a visszautasításos több processzoros ütemezés problémája megoldott az általános esetre, mivel versenyképesség szempontjából a lehetséges legjobb algoritmust ismerjük. A probléma 
optimálisan megoldására az $\operatorname{RTP}((\sqrt{5}-1) / 2)$ algoritmust használhatjuk. Másrészt sokszor a jobb versenyképességgel rendelkezô algoritmus rosszabb eredményt produkál az átlagos esetre, valós vagy generált adatokon. Az on-line ütemezés területén már láthattunk erre példát is [2], melyben a több processzoros ütemezési modell különbözô algoritmusait tesztelték és azt az eredményt kapták, hogy az egyszerü LISTA algoritmus [23] jobb eredményeket ért el, mint néhány jóval komplikáltabb, jobb versenyképességû algoritmus. Ebben a problémában az $\alpha$ paraméter optimális értéke $(\sqrt{5}-1) / 2$ a versenyképesség szempontjából, de kézenfekvô a kérdés, hogy a paraméter más értéke nem jobb-e az átlagos esetre.

Most bemutatunk egy új algoritmust, PAROLE (Parameter Online Learning), mely a futása során megpróbálja megtanulni a legjobb paramétert. Az algoritmus fázisokban múködik, minden fázis után választ egy új paramétert az input addig megismert része alapján. Először egy keretalgoritmust definiálunk, mely az új paramétert választó algoritmust eljárásként használja, majd megadjuk azt az eljárást is, mely a paraméter optimális értékét próbálja határozni az adott fázison. A fázisokat a beérkezett munkák száma alapján határozzuk meg, a fázis a 250. beérkezett munkával ér véget.

\section{A PAROLE algoritmus (i. fázis)}

- Az $i$ fázis kezdetekor a CHOOSE algoritmus meghatározza az $\alpha_{i}$ paraméter értékét.

- Hajtsuk végre $R T P\left(\alpha_{i}\right)$ algoritmust az inputon már ismert részén, $R$ halmazt is módosítjuk. 
- Használuk $R T P\left(\alpha_{i}\right)$-t a fázis alatt beérkezô munkákra.

Azt az $\alpha_{i}$ értéket szeretnénk használni, mely mellett $R T P\left(\alpha_{i}\right)(I)$ költség minimális az input már ismert részére. Sajnos a paraméter optimális értékének meghatározása nehéz, mert az $R T P(\alpha)(I)$ nem monoton és nem is folytonos függvénye $\alpha$-nak. A feltételezésünk, hogy az optimális $\alpha$ érték meghatározása egy NP-teljes probléma, de úgy túnik ezt nehéz bizonyítani. Ezért a következô mintavételezô algoritmust alkalmazzuk a paraméter új értékének meghatározására. Az algoritmus a paraméter megelôzô értékét is felhasználja, amit $\alpha^{*}$-al jelölünk.

\section{A CHOOSE algoritmus}

- Generálunk egy-egy értéket egyenletes eloszlással az $[(i-1) / 10, i / 10]$, $i=1, \ldots, 10$ intervallumokból. A kiválasztott értékek halmazát jelöljük $S_{1}$-el. Válasszuk ki $S_{1}$ halmaz azon $\alpha$ elemét, melyre $R T P(\alpha)$ nak a legkisebb költsége van $I$-n. Jelöljük ezt az értéket $\bar{\alpha}$-val.

- Generálunk egy-egy értéket egyenletes eloszlással az $\left[\alpha^{\star}-i / 100, \alpha^{\star}-\right.$ $(i-1) / 100],\left[\alpha^{\star}+(i-1) / 100, \alpha^{\star}+i / 100\right],[\bar{\alpha}-i / 100, \bar{\alpha}-(i-1) / 100]$, $[\bar{\alpha}+(i-1) / 100, \bar{\alpha}+i / 100]$ intervallumokból is, ahol $i=1, \ldots 10$. A kiválasztott értékek halmazát jelöljük $S_{2}$-vel. Legyen $\alpha$ az $S_{2} \cup$ $\left\{\alpha^{*}\right\} \cup\{\bar{\alpha}\}$ halmaz azon eleme melyre $I$ inputra az $R T P(\alpha)$-nak a legkisebb költsége van.

A CHOOSE alapötlete, hogy válasszunk egy jó paraméterértéket. Két jelölt szomszédságát vizsgáljuk meg, az egyik az előző paraméter értéke, a másik egy további $\bar{\alpha}$ érték, mely a legjobb egy sor olyan érték közül, melyeket az paraméter előző értékétôl függetlenül választottunk. 


\subsection{Hatékonysági vizsgálat}

\subsubsection{A végrehajtott tesztek ismertetése}

Az új paraméter tanuló algorimusunkat teszteknek vetettük alá, hogy a hatékonyságát értékeljük. A tesztek végrehajtásához valós adatokat és véletlen generált inputot is felhasználtunk.

A tesztek végrehajtásához a következô algoritmusokat vizsgáltuk.

- a Greedy algoritmus

- az $R T P(\alpha)$ algoritmus az $\alpha=(\sqrt{5}-1) / 2$ paraméterrel

- a parameter tanuló algoritmus (PAROLE).

Algoritmusok tesztelésének végrehajtásához a következô típusú bemeneteket konstruáltuk. Használtunk valós adatokat az A és B teszthez, továbbá az irodalomban használt [2] and [5] véletlen eloszlású adatokat generáltunk. Ezen eloszlások egy részének tipikus jellemzôje, hogy kis valószínûséggel nagyon nagy munkák is előfordulhatnak. Minden esethez elegendôen nagy méretû inputot használtunk, hogy a PAROLE-nak elég lehetősége legyen a paraméter értékének tanulására és a legjobb érték használatára.

- Teszt A (valós adatok): A szakoktatas.hu szerveren naplóztuk az egyes feladatok végrehajtási idejét. A naplófájlban körülbelül 100000 munka végrehajtási idejét gyưjtöttük össze, amit egy adattáblába gyűjtöttünk. A munkák átlagos mérete 2597.1, a szórásuk 20129.96. A legkisebb munka mérete 1, a legnagyobbé 3124460. Így a munkák 
mérete követte a fent leírt szituációt [2], azaz voltak nagyon nagy munkák is. A szerveren minden feladathoz egy prioritás érték volt rendelve, mely a feladat fontosságát és sürgősségét jellemezte. Ez a fontossági érték a következő jellemzókből tevődik össze: feladat tulajdonosa (minden felhasználónak is fontossági értéke van), a feladat típusa (a munkák feladatosztályokhoz vannak rendelve, a feladatosztályhoz pedig prioritási érték), továbbá néhány munkának határideje volt, amit szintén figyelembe vettünk egy változóval. Ezen érték lineáris kombinációját használtuk a visszautasítás büntetésére. Az átlagos büntetés 272.83, a szórás 229.32 volt. A minimális büntetés 1, a maximális 2613 volt.

- Teszt B (valós adatok): A moravarosi.hu szerveren is naplóztuk az egyes feladatok végrehajtási idejét. Az adatbázis k.b. 200000 munkát tartalmazott, és a végrehajtott munkák nagyobbak voltak mint az elôzô tesztnél. A munkák átlagos mérete 15608.96, míg a szórásuk 120991.53 volt. A legkisebb munka mérete 1, a legnagyobbé 18839728 volt. A munkákhoz tartozó prioritásokat az előzô teszthez hasonlóan használtuk fel, az átlagos büntetés 572.99 míg a szórás 481.58 volt. A minimális büntetés értéke itt is 1 míg a maximális érték 5487 volt.

- Teszt C (generált adatok): Ebben a tesztesetben a véletlent használva exponenciális eloszlású munkaméreteket generáltunk. Az eloszlás generálásához $\lambda=1 / 1000$ paramétert használtuk, így a várható érték 1000, a variancia 1000000 volt. A büntetések szintén exponenciális eloszlásúak voltak $\lambda=1 / 100$ a variancia itt 10000 volt. 
- Teszt D (generált adatok): Ebben a tesztesetben hiperexponenciális eloszlású munkaméreteket és büntetéseket generáltunk, 2 különbözô $\lambda$ értékkel. $\lambda_{1}=1 / 800$ és $\lambda_{1}=1 / 1200$ értékeket használtunk a munkák generálására, mindkét esetben $p_{2}=1 / 2$ értéket használva. Ezért a munkák várható értéke itt $p_{1} / \lambda_{1}+p_{2} / \lambda_{2}=1000$, a variancia 1080000. A büntetésekre vonatkozó paraméterek $\lambda_{1}=1 / 80$ és $p_{1}=$ $1 / 2$ valamint $\lambda_{2}=1 / 120$ és $p_{2}=1 / 2$, így a várható érték 100 , a szórás értéke 10800 volt.

- Teszt E (generált adatok): Ebben a tesztesetben az Erlang2 eloszlású munkaméreteket és büntetéseket generáltunk. A használt paraméterek a munkák esetében $\lambda=500$, így a várható érték 1000, a szórás 500000 volt a büntetések esetében $\lambda=1 / 50$, a várható érték 100, a szórás 5000 volt.

- Teszt F (generált adatok): Ebben a tesztesetben a véletlent használva korlátos Pareto-eloszlású munkaméreteket és büntetéseket generáltunk. A munkák generálásához $B(k, p, \alpha)$-ban k (a legkisebb munka méretének korlátja) 1, p (a legnagyobb munka méretének korlátja) 20000 volt. Az $\alpha$-t úgy választottuk, hogy a várható érték 1000 legyen. A büntetéseket ugyanígy generáltuk, azzal a különbséggel, hogy a felső korlát 1000 és a várható érték 100 volt.

A valós adatokon végzett analízisnél kétféle tesztet végeztünk, egy nagy méretú (NAGY) inputon mely az összes munkát tartalmazta, és egy kis méretút (KICSI), ami csak a munkák 20\%-át. A tesztek végrehajtásánál végig 10 gépre ütemeztünk. Az eredmények összesítése a 9. táblázatban 
található. A generált adatokon végzett teszteknél szintén kétféle inputméretet használtunk, a nagyobb méretú (NAGY) 1000 000, a kisebb (KICSI) 10000 munkát tartalmazott, és szintén 10 gépre ütemeztünk. Minkét esethez 100-100 generált adatsoron végeztük el a teszteket, a tesztek eredményeinek átlagát a 10. táblázatban összesítettük.

9. táblázat. Teszteredmények a valós adatokon

\begin{tabular}{|c|c|c|c|c|}
\hline & A(KICSI $)$ & A(NAGY $)$ & B(KICSl) & B(NAGY) \\
\hline Greedy & 883549 & 4326745 & 2813479 & 13976483 \\
RTP & 843756 & 4117672 & 2889437 & 14245263 \\
PAROLE & 843679 & 4118935 & 2876559 & 14169854 \\
\hline
\end{tabular}

10. táblázat. Átlagolt eredmények a generált adatokon

\begin{tabular}{|c|c|c|c|c|}
\hline & C(KICSI) & C(NAGY) & D(KICSI) & D(NAGY) \\
\hline Greedy & 7487543 & 713456754 & 7964338 & 701341876 \\
RTP & 6822435 & 674523268 & 7657424 & 731735218 \\
PAROLE & 7014345 & 698764525 & 7776885 & 707823932 \\
\hline & E(KICSI) & E(NAGY) & F(KICSI) & F(NAGY) \\
\hline Greedy & 5698614 & 498238711 & 6718917 & 614492728 \\
RTP & 5254355 & 476521848 & 6396234 & 592718325 \\
PAROLE & 5317817 & 475632194 & 6512922 & 595598238 \\
\hline
\end{tabular}

A visszautasított munkák számát is vizsgáltuk. Nagy különbséget tapasztaltunk az A és B teszt között, míg A tesztben a munkák 25\%-a lett visszautasítva, addig B tesztnél ez az érték 42\% körüli. Ez várható volt, hiszen a B tesztben a büntetések és a munkák végrehajtási idejének arányának várható értéke kisebb (az A tesztben 0.105, a B tesztben 0.037). 
A generált adatokon végzett tesztek esetében a visszautasított munkák aránya 22 és 30 százalék körül mozgott.

Az eredmények alapján megfigyelhető, hogy a Gredy algoritmus kevesebb munkát utasított el, mint az RTP algoritmus. Ezt is vártuk, hiszen a Gredy algoritmus minden az RTP és PAROLE algoritmusok által visszautasított munkát visszautasít.

A költségek két típusára vonatkozóan megállapíthatjuk, hogy Gredy fizeti a legkevesebb büntetést és RTP a legtöbbet, viszont csak kis különbség mutatkozik a befizetett büntetések összegét illetôen, a különbség az összes esetben 2\%-nál kisebb. A különböző tesztek alatt a büntetések összege a teljes költség 35-45 százaléka volt, kivéve a B teszt esetében, ahol ez a szám $60 \%$.

\subsubsection{Az eredmények értékelése}

Az eredmények értékelése alapján az alábbi következtetéseket vonhatjuk le:

- Az összes tesztesetben csak kicsi különbség mutatkozik az egyes algoritmusok hatékonyságában. A legnagyobb arány a C(Kicsi) teszt eredményében volt mérhető a Greedy/RTP hányados értékében, mely 1.098. A legtöbb esetben a legjobb és legrosszabb megoldás között 1.05 alatti.

- Az RTP algoritmus 6 teszt esetén adott legjobb megoldást ,a PAROLE algoritmus 4 tesztesetben míg Greedy 2 esetben. A PAROLE algoritmus viszont egyik esetben sem adta az algoritmusok közül a 
legrosszabb megoldást. Így elmondható, hogy Parole vagy a legjobb teljesítményt nyújtja, vagy a hatékonysága a másik két algoritmusok között helyezkedik el.

- A tapasztalati vizsgálatok eredményei alapján az is elmondható, hogy a Gredy algoritmus jobb teljesítményt nyújt nagyobb inputon. Úgy gondoljuk ez azért van, mert a Gredy algoritmus nagy inputok esetén könnyeben javíthatja egy rossz döntésének következményeit (amikor egy nagy munkát fogad el, amikor azt el kellene utasítania).

- Feltételeztük, hogy a Gredy algoritmus kevesebb munkát utasít el, így kevesebb büntetést fizet, mint a másik két algoritmus és RTP fizeti a legtöbb büntetést. A tesztek igazolták, hogy feltételezésünk igaz. Úgy tûnik, hogy PAROLE óvatosabban utasítja el a munkákat mint RTP. Azt is láthatjuk azonban, hogy nincs jelentős különbség az visszautasított munkák számában a tesztesetek adatain és ebben a tekintetben mindhárom algoritmus hasonló viselkedést mutat.

Az elemzés eredményeit összefoglalva arra a következtetésre jutottunk, hogy általában a PAROLE algoritmus hatékonysága a többi algoritmus hatékonysága között van, sốt az algoritmus által generált célfüggvényérték mindig az optimális célfüggvényértékhez közelít, ezért abban az esetben mindenképpen jól használható az on-line feladatokon, amikor nincs információnk az input egyes paramétereiról. 


\section{Fejezet}

\section{On-line klaszterezés egy RTLS rendszerben}

Ebben a fejezetben matematikai modellt és megoldásokat javaslunk és értékelünk egy on-line klaszterezési problémára. A probléma gyakran felvetődik a folytonos adatfeldolgozási rendszerekben, mint például a valós idejû́ helymeghatározási rendszerekben is. Cél a lehetô legtöbb forrásból származó információt összegyưjteni, de minimalizálni az összegyưjtött információk továbbítása/feldolgozása előtti várakozási időt. A valós idejû helymeghatározó rendszerek adatgyújtố moduljainak legfontosabb jellemzője, hogy az egy időpontban különböző mérésekból (távolságadatok, beesési szögek) származó adatokból egy csomagot kell kialakítani, amit a pozíciómeghatározáshoz fel tudunk használni. Megadunk egy általános matematikai modellt a probléma kezelésére, és két alapvetô algoritmus az NWT és CWT algoritmust, melyeket versenyképességi elemzésnek vetünk alá, majd egy új algoritmust (VWT) mutatunk be a probléma megoldására, mely a problémát megszorítások nélkül kezeli. Ezt az algoritmust teszteljük valós körülmények között, hogy belássuk, ez az algoritmus megszorítások nélküli megoldást ad a problémára. 


\subsection{Elôzmények}

A fejezetben bemutatott probléma a Fraunhofer IIS intézetben folytatott on-line lokalizációs rendszer fejlesztése közben merült fel, de maga a probléma általános, így az itt bemutatott matematikai modell is az. Az, hogy a származási helyével együtt mutatjuk be a problémát, segít megérteni, hogy a bevezetett megszorítások mit jelentenek egy valós alkalmazásban.

A valós idejú helymeghatározó rendszerek feladata a különböző objektumok pozíciójának nagy pontosságú meghatározása, mely adatokat sok különbözô alkalmazásban használnak fel. Ilyen alkalmazások például a szállítmányozás és logisztika, az otthoni idôs és betegápolás, a sürgôsségi betegellátás támogatása, vagy a különböző szórakoztató és sport alkalmazások amilyen például a Chip-in-the-Ball technológia. Az említett valósidejú helymeghatározási rendszer egy rádiófrekvenciás változatának fejlesztésében vettünk részt a Fraunhofer IIS projektje keretében. A rendszer egy-egy mérőállomása a célobjektum által sugárzott rádiójel beesési szögét továbbá a visszaverôdési idejét méri, és a térben különböző pozíciókban elhelyezett mérőállomások mérési adatai alapján határozza meg az objektum pozícióját egy adott pillanatban [8, 9].

A rendszerben az objektumok olyan miniatúr rádióadókkal vannak felszerelve, melyek egy az Intézet által kifejlesztett beltéri múködésú valós idejú pozíció-megahtározási rendszer (WISMIT) által feldolgozható periodikusan sugárzott rádiójeleket küldenek. Ezeket a rádiójeleket fogják az 
infrastruktúra különbözô mérőállomásai, melyek a jelek beesési szögét és a rádiójelet sugárzó objektum távolságát tudják meghatározni minden periódusban (mérési ciklusban). Egy ilyen mérési sorozatot melyen a periodikusan sugárzott rádióimpulzusok egyetlen impulzusát különbözó pozíciókban elhelyezett mérőeszközök méréseit értjük, burst-nek nevezünk. A rádió jelek különböző feldolgozható információkat is közvetítenek, egyrészt egy egyedi azonosítót, ami egyértelmúen azonosítja azt az objektumot amiból a rádiójel származik, másrészt egy folyamatosan növekvô sorszámot ami a mérési ciklusokat számolja így azonosítva egy-egy mérési ciklust (burst-öt). Ezt a mérési ciklust azonosító sorszámot burst_id-nek nevezzük.

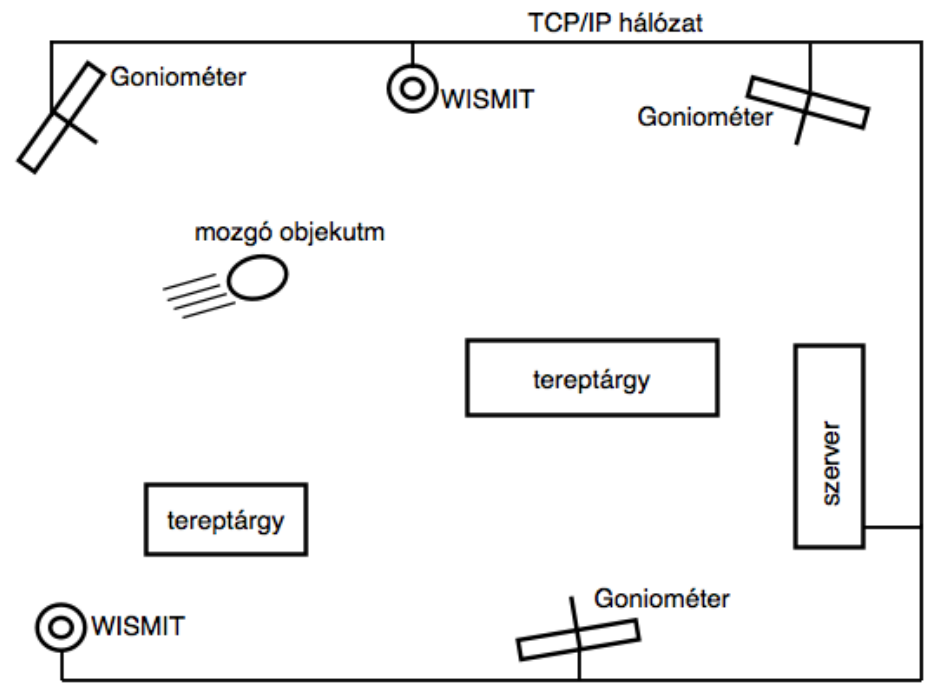

7. ábra. A mérési infrastruktúra sematikus rajza

Az helymeghatározást végzô infrastruktúra részeiként múködő kü- 
lönbözố mérést végzô eszközök egyrészt az objektum irányát képesek meghatározni a beesési szög mérésével, az ilyen mérést AoA adatnak hívjuk, másrészt a visszaverôdési idô méréséből az objektum távolságát, amit RTT értéknek nevezünk. A rendszerben két különböző típusú mérőeszközt lehet installálni. Az egyik a WISMIT eszköz, mely csak a visszaverôdési idôt méri, majd meghatározza az RTT értékét és továbbítja az adatot. A másik mérôeszköz a Goniométer, mely visszaverődési idôt és beesési szöget is mér így mind RRT mind AoA értéket számít és továbbít. A mérési infrastruktúra sematikus rajzát az 5. ábra szemlélteti.

A mérési infrastruktúra pontjain mért adatok a mérôeszközöktől egy TCP/IP hálózaton jutnak el a pozíció számítást végzô számítóképhez UDP átviteli protokollon keresztül. Az UDP csomagok a TCP folyammal ellentétben sokkal gyorsabb de kevésbé biztonságos adattovábbítást tesz lehetôvé, ugyanis, ha egy mérési eredményt továbbító csomag elveszik vagy sérül nincs idő ennek a detektálására, az esemény visszajelzésére és a csomag újraküldésére. A pozíciót meghatározó algoritmusnak így az adott mérés nélkül kell az objektum pozícióját meghatározni, az adott idôpillanatra. További adatvesztés oka lehet, ha az objektum mozgása folyamán olyan pozícióba kerül, hogy egy tereptárgy kitakarja a mérőeszköz elől az objektumot így a mérőeszköz nem tudja mérést végrehajtani, nem kapja meg az objektum által sugárzott rádiójelet, így az adott pillanatban nem is küld a pozíciómeghatározás számára használható mérési eredményt. Tehát több okból nincs garancia arra, hogy minden mérési ciklusban minden mérési eredményt megkapunk. Ha egy mérési ciklusban elegendő mérési adatot összegyưjtünk, a mérési eredményekból a pozíciót kiszámító 
algoritmus már ki tudja számítani az objektum pozícióját. Nyilvánvaló, hogy minél több mérési eredményünk van, a pozíció meghatározása annál pontosabb. A nyers mérési eredményektôl a következő lépéseken jut el az adat a pozíció kiszámításáig:

1. Nyers adatszứró

2. Klaszterezés

3. Burst szứố

4. Pozíciómeghatározás

5. Pozíció szứrô

A lépések többségének az is feladata, hogy a mérések pontatlanságából és egyéb hibákból, fizikai jelenségekből származó zajt és hibát csökkentsék.

Ebben a munkában a második lépésre fókuszálunk, a klaszterezési komponensre. Ennek a lépésnek elsôdleges célja, hogy, a burst-höz a lehetô legtöbb mérési adatot összegyújtse, és amilyen hamar csak lehetséges továbbítsa az összegyújtött adatokat a Burst szúrôhöz majd onnan a pozíció számításhoz. Ehhez on-line módon kell klaszterezni az infrastruktúra mérési pontjaitól kapott adatokat. Itt számolni kell az átviteli hibákkal és zavarokkal, mint a mérési infrastruktúra mérési pontjainak átmeneti takartsága, vagy az egyes hálózati csomagok elvesztése, illetve a változó adattovábbítási és feldolgozási időkkel. Így a klaszterezô algoritmus nem várhatja egyszerúen minden mérési eredmény beérkezését, ennél jóval kifinomultabb megoldásra van szükség. A cél az, hogy az algoritmus döntse el mikor érdemes az összegyűjtött adatokat a pozíció számításhoz 
továbbítania. Ehhez két egymásnak ellentmondó célnak kell megfelelnie. Az elsố, hogy a pozíció számító algoritmusnak az összes rendelkezésre álló mérési adatot meg kell kapnia a mérési pontoktól, a lehető legpontosabb pozíciómeghatározás érdekében. Ugyanakkor a rendszernek nem szabad túl sokáig várnia a mérési adatok begyưjtésére, hiszen minden késedelem az adattovábbításban jelentôsen rontja a mozgó objektumra meghatározott pozíció relevanciáját. Egy majdnem pontos pozíció jobb, mint egy teljesen pontos pozíció túl későn. Bemutatunk egy a fenti irányelveket célzó integrált célfüggvényt, és a klaszterezési problémát maximalizációs problémaként definiáljuk. Mivel minden részfolyamat, mint az adatok gyújtése vagy a pozíció kiszámítása is több objektumra párhuzamosan, egymástól függetlenül végrehajtható, az egyes objektumok pozíciómeghatározását külön problémaként kezeljük, így úgy tekinthetjük, hogy csak egyetlen objektum pozícióját kell meghatározni. Megjegyezzük, hogy a probléma hasonlít az on-line nyugtázási problémához, ahol a cél szintén az, hogy határozzuk meg a nyugtázás elküldésének optimális időpontját. Az egyik bemutatott algoritmus épp az ébresztő algoritmus ötletét használja, amit a nyugtázási probléma megoldására használnak.

Most bemutatjuk a probléma matematikai modelljét, adunk egy célfüggvényt és elemezzük az egyes algoritmusok versenyképességét. Két eset analízisét mutatjuk be, az elsô akkor használható, ha nincs felsô korlát az adatok beérkezési idejére, a második akkor, ha számolhatunk egy felsô korláttal, mely idő alatt az összes mért adat beérkezik. Ez a modell jobban leírja a rendszer viselkedését és jobb eredményeket kapunk. 


\subsection{A probléma matematikai modellje}

A klaszterezési probléma inputja egy $X: x_{1}, \ldots, x_{n}$ sorozat, a pozíciómeghatározás során mért adatok összessége. A következô jelöléseket fogjuk használni: Burst $\left(x_{i}\right)$ azt a burst_id-t jelöli, mely megadja, hogy $x_{i}$ mérési adat melyik mérési ciklusból származik. $N o d e\left(x_{i}\right)$ a valós idejû pozíciómeghatározó rendszer infrastruktúrájának azt a mérôegységét (WISMIT, Goniométer) jelöli, amelyik $x_{i}$ adatot mérte majd továbbította a szervernek. $R c p t\left(x_{i}\right)$ az $x_{i}$ adat beérkezési időpontját jelöli. A mérési ciklus (burst) utolsó és elsô elemének beérkezési idôpontja közötti különbség a burst hossza. Megjegyezzük, hogy a mérési adatokról további információk is rendelkezésre állnak, például az, hogy az adat milyen típusú mérési eredményt tartalmaz (AoA vagy RTT érték), amik a pozíciómeghatározás szempontjtából fontosak, de ezek az információk a klaszterezô algoritmus szempontjából lényegtelenek. $B_{j}=\left\{x_{i} \mid \operatorname{Burst}\left(x_{i}\right)=j\right\}$ halmaz a burst adatcsomag és $B_{j}^{\prime} \subseteq B_{j}$ a burst adatcsomag részhalmaza, mely a pozíció számítás részére elküldött adatokat tartalmazza. Azt az idôpontot amikor az algoritmus úgy dönt elküldi $B_{j}^{\prime}$-t a pozíció számításhoz $p_{j}$-vel jelöljük, ahol $j=1, \ldots, b$ és $b$ a burst-ök száma. Ezeket a halmazokat és ezek idôbeni elhelyezkedését a 6 . ábra mutatja.

Ha a mérési infrastruktúra egyes mérőállásai különböző technikai paraméterekkel rendelkeznek (típus, pozíció) akkor a róluk begyújtött adatoknak is különböző fontosságuk lehet a pozíció meghatározásában. Ezért minden mérési ponthoz hozzárendelünk egy-egy $w_{k}>0$ súlyt, ami a mérési ponton begyưjtött adat fontosságát mutatja. Az általánosság megszorítása 


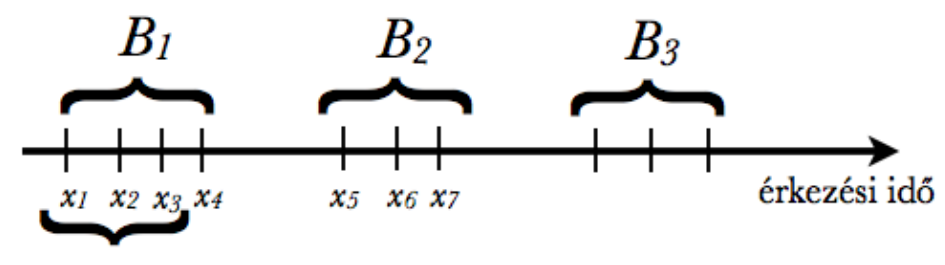

\section{Alg.}

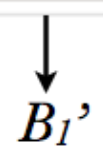

8. ábra. Bemeneti jelek csoportosítása

nélkül feltételezhetjük, hogy $w_{1}=\min _{k=1}^{m} w_{k}$, ahol $m$ a valós idejú pozíciómeghatározási infrastruktúra mérési pontjainak (mérőállomásainak) számát jelöli.

Az algoritmusok értékeléséhez először definiálunk egy célfüggvényt, mely mutatja azok hatékonyságát. Ennek olyannak kell lennie, ami mindkét célt figyelembe veszi: minél kevesebb adat elvesztése mellett minél kevesebb ideig várakozzon, mielőtt a pozíció számítást elkezdi. A célfüggvény meghatározásához a következô jelöléseket használjuk. Minden adattovábbítási $p_{j}$ idôponthoz és $k$ mérési helyhez legyen $e_{j k}=1$, ha a mérési adatot továbbítottuk a pozíció számításhoz egyébként legyen $e_{j k}=0$.

Legyen

$$
r_{j}=\max _{i=1}^{n}\left\{\operatorname{Rcpt}\left(x_{i}\right) \mid x_{i} \in B_{j}^{\prime}\right\}
$$

A következô maximalizálandó célfüggvényt definiáljuk: 


$$
f=\sum_{j=1}^{b} \sum_{k=1}^{m} e_{j k} w_{k}-c \sum_{j=1}^{b}\left(p_{j}-r_{j}\right)
$$

Az elsố tag azon adatok fontosságát veszi figyelembe a jutalmazáshoz, melyeket elküldünk és így felhasználtunk a pozíció számításhoz, a második tag a küldés késedelmét bünteti egy konstans szorzóval. Ez csak akkor helyes, ha $c>0$.

Megjegyezzük, hogy lehetséges egy minimalizációs problémát is definiálni a modellhez, amely az elvesztett csomagok súlyozott számának és a késlekedésnek az összege, de ebben az esetben az optimális off-line algoritmus 0 célfüggvényértéket produkálhatna, ami lehetetlenné teszi a versenyképességi elemzést. Ezért döntöttünk úgy, hogy a fejlesztés során a célfüggvény maximalizálandó változatát használjuk.

\subsection{Versenyképességi elemzés}

\subsubsection{Az általános modell}

Először azt feltételezzük, hogy nincsenek további megszorítások az inputra vonatkozóan. Meg fogjuk mutatni, hogy erre az esetre nincs az alábbi alsó korlátnál kisebb versenyképességi hányadossal rendelkezô algoritmus.

7. Tétel. Nincs olyan algoritmus melynek a versenyképességi hányadosa kisebb, $\operatorname{mint} \frac{\sum_{k=1}^{m} w_{k}}{w_{1}} \geq m$. 
Bizonyítás: Tekintsük a következô inputot. Legyen az elsô adatra a burst_id $=1$, a node_id $=1$ és az érkezési idôpontja 0 . Ha az on-line algoritmus $p_{1} \geq \frac{w_{1}}{c}$ idôpontot választja az adatok továbbküldésére, akkor a sorozat véget ér és az on-line nyereség nem pozitív, míg az off-line algoritmus használhatja a $p_{1}^{o p t}=0$ idôpontot az adattovábbításhoz, így a nyeresége $w_{1}$. Ebben az esetben tehát az algoritmus nem versenyképes. Most tegyük fel, hogy $p_{1}<\frac{w_{1}}{c}$. Ekkor $m-1$ további adat érkezik 1-es burst_id-val és $2, \ldots, m$ node_id-val a $\frac{w_{1}}{c}$ idôpontban. Eben az esetben az on-line algoritmus nyersége legfeljebb $w_{1}$, míg az optimális off-line algoritmus a $p_{1}^{o p t}=\frac{w_{1}}{c}$ idôpontban küldi tovább az adatokat, így a nyeresége $\sum_{k=1}^{m} w_{k}$

Az NWT Algoritmus Az elóbbi alsó korlát mutatja, hogy a legrosszabb eset, ha a hiányzó adatok épp a már megérkezett adatok elküldése után érkeznek. Ezért az on-line algoritmusnak nincs oka várni további adatokra, miután az elsố adat megérkezett, érdemes azt azonnal továbbküldenie. Az NWT (No Waiting Time Algorithm) algoritmus ezen az észrevételen alapul, tehát minden burst-höz az elsô adatot küldi tovább a pozíció kiszámításához, amint az megérkezett. Az algoritmus versenyképességi hányadosa az alábbi.

8. Tétel. Az NWT algoritmus versenyképességi hányadosa $\frac{\sum_{k=1}^{m} w_{k}}{w_{1}}$.

Bizonyítás: Tekintsük az input egy tetszóleges b számú burst-öt tartalmazó sorozatát. Minden burst-nél a burst elsô elemét továbbítja az 
algoritmus, így a nyereség legalább $b \cdot w_{1}$. Az optimális off-line nyereség viszont maximum $b \cdot \sum_{k=1}^{m} w_{k}$.

1. Következmény. NWT a lehetố legkisebb versenyképességi aránnyal rendelkezó algoritmus az általános modellben.

\subsubsection{A korlátos modell}

Ebben a részben egy további megszorítást adunk a bemenet tulajdonságaira, hogy jobban modellezhessük a fizikai rendszer múködését. Feltesszük, hogy egy burst nem lehet akármilyen hosszú, azaz ugyanazon burst_id melletti adatcsomagokra az elsônek és utolsónak beérkezett adat beérkezési időpontjai között eltelt idő nem lehet $d$-nél nagyobb. Most tegyük fel, hogy $\frac{w_{1}}{c}>d$, egyébként az általános eset alsó korlátjának bizonyítása alapján itt is beláthatjuk, hogy az NWT algoritmus a lehető legkisebb versenyképességi hányadossal rendelkezik.

9. Tétel. Nincs olyan algoritmus a korlátos modellben, melynek kisebb a versenyképességi hányadosa mint $\min \left\{\frac{w_{1}}{w_{1}-c \cdot d}, \frac{\sum_{k=1}^{n} w_{k}}{w_{1}}\right\}$.

Bizonyítás: Tekintsük a következô inputot. Legyen az elsô adatra a burst_id $=1$, a node_id $=1$ és az érkezési idôpontja 0 . Ha az on-line algoritmus az $p_{1} \geq d$ időpontot választja az adatok továbbküldésére, akkor a sorozat véget ér, az on-line nyereség $w_{1}-c \cdot p_{1} \leq w_{1}-c \cdot d$. Az off-line algoritmus a $p_{1}^{o p t}=0$ idôpontot választja az adatok továbbítására, így az off-line nyereség $w_{1}$. Ebben az esetben tehát az on-line algoritmus nem lehet jobb, mint $\frac{w_{1}}{w_{1}-c \cdot d}$-versenyképes. Most tegyük fel, hogy $p_{1}<d$. Ekkor 
$m-1$ további adat érkezik 1-es burst_id-val és $2, \ldots, m$ node_id-val a $\frac{w_{1}}{c}$ időpontban. Eben az esetben az on-line algoritmus nyeresége legfeljebb $w_{1}$, míg az optimális off-line algoritmus a $p_{1}^{o p t}=\frac{w_{1}}{c}$ idôpontban küldi tovább az adatokat, így a nyeresége $\sum_{k=1}^{m} w_{k}$.

A CWT (Constant Waiting Time) algoritmus minden burst-nél az elsô adatcsomag megérkezése után vár még $d$ ideig, majd elküldi az összes addig megérkezett adatot a pozíció meghatározónak.

10. Tétel. A CWT algoritmus versenyképességi hányadosa $\frac{w_{1}}{w_{1}-c \cdot d}$.

Bizonyítás: Tekintsünk egy tetszőleges olyan $X$ bemenetet, mely $b$ burstöt tartalmaz. A korlátozott várakozási idő miatt az algoritmus minden adatot összegyújt minden burst_id mellett. Ezért az összes nyereség legalább $G-b \cdot c \cdot d$, ahol $G$ a bejövô adatokon összegyújthetô nyereségek összege. Másfelól az optimális nyereség sem lehet több mint $G$, és $G \geq b \cdot w_{1}$. Ezért a CWT algoritmus versenyképességi hányadosa legfeljebb

$$
\frac{G}{G-b \cdot c \cdot d} \leq \frac{w_{1}}{w_{1}-c \cdot d}
$$

2. Következmény. A korlátos modellben $h a \frac{w_{1}}{w_{1}-c \cdot d} \leq \frac{\sum_{k=1}^{m} w_{i}}{w_{1}}$, akkor CWT versenyképességi hányadosa a modellben lehetséges legkisebb versenyképességi hányados, egyébként NWT versenyképességi hányadosa éri el a lehetséges legkisebb értéket. 


\subsection{Tapasztalati elemzés}

Ahogy az elôzố részben láttuk, néhány egyszerû algoritmussal elérhetjük az egyes modellekben a lehetô legjobb versenyképességi arányt, de a hatékonyság a $d$ paraméter értékének pontos ismeretétól függ. Ebben a részben először bemutatunk egy sokkal kifinomultabb algoritmust, ami a $d$ paraméter rendszerre jellemzó értékének ismerete nélkül megpróbálja annak értékét a beérkezô adatok alapján folyamatosan megbecsülni, annak idóbeni változásával együtt. Egy mérésen alapuló tapasztalati elemzést is bemutatunk, mely az algoritmusok hatékonyságát vizsgálja a tényleges környezet által gyưjtött adatokon, így következtetéseket tudunk levonni azok átlagos viselkedésére vonatkozóan.

\subsubsection{A VWT Algoritmus}

Ebben az algoritmusban minden $j$ burst_id-hoz tartozik egy $S(j)$ kezdeti időpont, mely az első olyan adat beérkezési időpontja, melynek a burst_id-ja $j$. Továbbá minden burst-hoz egy adott idôpontban egy $D S(j)$ adathalmaz tartozik, mely a burst az adott időpontban már összegyújtött adatelemeit tartalmazza. (Ezt fogjuk $B_{j}^{\prime}$-vel jelölni, abban az időpontban, amikor továbbítjuk a pozíciószámításhoz.) Az algoritmus egy $t$ változót használ a várakozási idô tárolására, mely azt mutatja, mennyit vár az algoritmus egy burst adatainak begyújtésére. Az algoritmus ennek a várakozási időnek az optimális értékét próbálja megtanulni. Hasonló paraméter tanuló algoritmusokat láthattunk az előzố 2 fejezetben, az 
on-line nyugtázási problémára [28], valamint az on-line ütemezésre [31] is. Az algoritmus további két paramétert is használ, a $D E C$ ész az $I N C$ paramétereket, az elsố egy alsó korlátot ad a $W$ változó értékének lehetséges csökkentésére, $I N C$ pedig egy biztonsági távolság, melyet a $t$ értékhez adunk abban az esetben, ha $W$ értékét növelni kell. $M E M$ egy paraméter, mely azt határozza meg, az algoritmus milyen hosszan (hány burst-re) tartja nyílván a korábban elküldött burst-ök maximális hosszát.

Az algoritmus a következô szabályokat használja, az adatok elküldési időpontjának meghatározására és az adatok küldésére:

- Ha az aktuális idő $S(j)+W$ és $D S(j)$ még nem lezárt (nincs továbbítva a pozíció számításhoz), akkor az algoritmus lezárja $D S(j)$-t, és elküldi azt a pozíció számító algoritmusnak. Egyébként legyen

$$
P D(j)=\max \left\{0, \min _{a=0}^{M E M-1}\left\{p_{j-a}-r_{j-a}\right\}-I N C\right\}
$$

a $W$ változó lehetséges legkisebb csökkentési értéke, mely az utolsó $M E M$ burst minimális hosszát és az $I N C$ biztonsági időt veszi figyelembe. Ha $P D(j) \geq D E C$, akkor $W$-t csökkentjük $P D(j)$-vel.

- Ha az algoritmus a burst összes adatát összegyújtötte $D S(j)$-be, azaz $t$ várakozási idô elég volt ahhoz, hogy a pozíciómeghatározási infrastruktúra összes mérési adatát összevárjuk, akkor az összegyújtött adatokat $D S(j)$-t továbbítjuk a pozíció meghatározáshoz. Ez csak úgy történhetett, ha $t \leq S(j)+W$. Ilyenkor az előző pont szerinti a $W$ értékének csökkentése is megtörténhet. 
Az algoritmus a következő szabályokat használja az $x_{i}$ adat megérkezésekor:

- Ha $x_{i}$ a $j$ burst-höz tartozik, $t$ idôpontban érkezik és $D S(j)$ nincs lezárva, akkor bôvítjük $D S(j)$-t az új adattal és ellenôrizzük, hogy van-e még a $j$ burst-höz tartozó hiányzó adat az infrastruktúrából.

- Ha $D S(j)$ már lezárt az $r_{j}$ idôpontban $W$ értékét módosítjuk a $t-S(j)+I N C$ értékre.

\subsubsection{Hatékonysági vizsgálat}

Az algoritmus hatékonyságának vizsgálatához az Fraunhofer Intézet szimulációs eszközét használtuk. A szimulációs szoftver egy virtuális objektumot mozgat egy elöre megadható útvonalon. Ennek a virtuális objektumnak a pozícióját mérik a virtuális mérési térben elhelyezett különbözô mérőeszközök, a mi mérésünkben 3 goniométer (mely RTT és AoA adatokat gyújt) és 8 távolságmérô (csak RTT adatokat gyújt). A következő események véletlenszerúen történnek a szimulációs rendszerben a szimuláció futása közben:

- Minden mérési adat, amit a virtuális infrastruktúra mérôeszközei küldenek egy adott valószínúséggel elveszik. (Ez a valószínúség különkülön definiálható a minden mérôeszközre az RTT és AoA adatokra.)

- Az eltelt idő két burst között és a burst-ön belül két adat továbbítása között is normális eloszlású.

A tesztek végrehajtásához a következő 6 bemenetet generáltuk. Az A és B tesztben rendre 68 és 262 burst (mérési sorozat) alatt 952 és 
3668 adat érkezett, a burst-ök átlagos hossza 2.04 és 2.6 volt. A C és D tesztekben rövidebb burst-öket generáltunk, az átlagos bort hossz 0.99 és 1.06 volt. A C tesztben 131 burst 1800 adatot míg a D tesztben 138 burst 1932 adatot tartalmazott. Végül az E és F tesztekben sokkal hosszabb burst hosszt alkalmaztunk, az átlagos burst hossz itt rendre 34.07 és 35.9 volt. Az E tesztben 127 burst 1742, míg az F tesztben 879 burst 12079 adatot tartalmazott.

Három különböző CWT algoritmust konstruáltunk. A CWT(1) egy kisebb $d$ konstanst használt, amit a $\mathrm{C}$ és $\mathrm{D}$ tesztek átlagos burst-hosszaihoz igazítottunk. A CWT(2) egy nagyobb konstanst használt, amit az E és F tesztek átlagos burst hosszaihoz, a CWT (3) pedig ennél még kicsit nagyobb konstanst. A 11. táblázatban az optimális nyerseség és az algoritmus által elért nyereség hányadosát tüntettük fel. Minden $i$-hez a $w_{i}=0.07$ és $c=0.01$ értéket használtuk a célfüggvényben.

\begin{tabular}{|l|r|r|r|r|r|r|}
\hline & Teszt A & Teszt B & Teszt C & Teszt D & Teszt E & Teszt F \\
\hline CWT(1) & 0.930 & 0.883 & 0.967 & 0.964 & 0.142 & 0.194 \\
\hline CWT(2) & 0.730 & 0.736 & 0.715 & 0.721 & 0.794 & 0.759 \\
\hline CWT(3) & 0.660 & 0.666 & 0.643 & 0.651 & 0.976 & 0.936 \\
\hline VWT & 0.976 & 0.985 & 0.978 & 0.984 & 0.985 & 0.914 \\
\hline
\end{tabular}

11. táblázat. A tesztek eredményei

Az eredmények alapján az alábbi következtetéseket vonhatjuk le:

- Tisztán látszik, hogy a CWT algoritmusok hatékonysága erôsen függ a burst-ök átlagos hosszától. A CWT(1) jó eredményeket produkált 
az $\mathrm{A}, \mathrm{B} \mathrm{C}$ és $\mathrm{D}$ tesztesetben, viszont nagyon rosszakat az $\mathrm{E}$ és $\mathrm{F}$ tesztesetekben. A CWT(2) és CWT(3) algoritmusok viszont az E és F tesztesetekben voltak hatékonyabbak, a többi tesztesetben viszont gyöngébb teljesítményt nyújtottak. Ez azt jelenti, hogy ezek az algoritmusok csak akkor lennének használhatók valós körülmények között, ha elôre több információnk lenne a mérési infrastruktúra felépítésébôl adódó jellemzôkrốl amik a burst hosszát befolyásolják (és ezek a futás során sem változnának). Ebben az esetben ugyanis ezek az algoritmusok is jól múködhetnek, a hatékonyságuk minden ilyen tesztesetben 0.9 feletti.

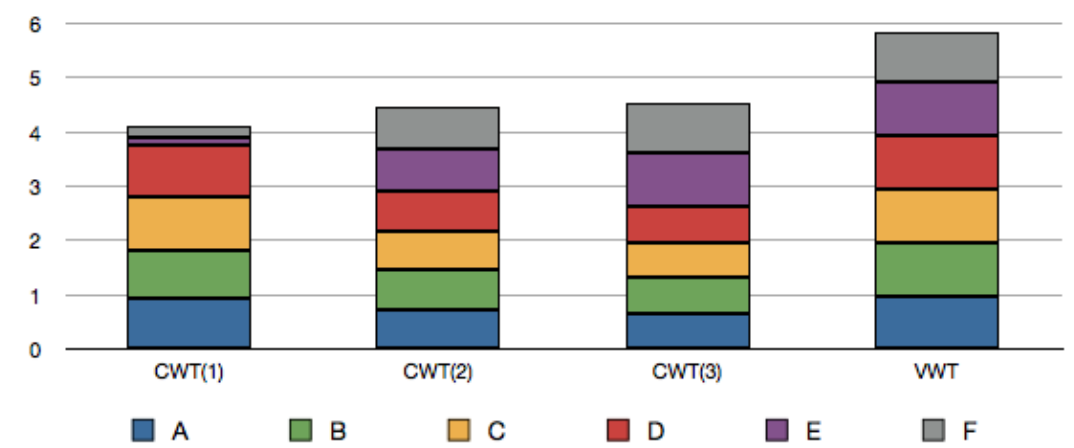

9. ábra. Az egyes algoritmusok hatékonysága

- A VWT algoritmus ezzel ellentétben minden tesztesetben hatékonyan múködött, a nélkül, hogy előre ismertük volna az infrastruktúra fizikai jellemzőibool és felépítésébôl adódó maximális várakozási idôt. Az algoritmus hatékonysága a legrosszabb esetben is 0.914, az átlagos arány pedig 0.97 volt. 
A 7. ábrán jól látható, hogy az új paraméter tanuló algoritmus (VWT) lényegesen jobb hatékonysággal múködik az átlagos esetben, mint a legjobb versenyképességi aránnyal rendelkező CWT algoritmus, a nélkül is, hogy előzetes információja lenne a mérési infrastruktúra fizikai jellemzőiból adódó maximális burst-hosszról.

\section{5. Áttekintés és nyitott kérdések}

Ebben a fejezetben egy on-line optimalizációs modellt definiáltunk, az on-line klaszterezés problémájában, mely probléma a valós idejű helymeghatározási rendszerek fejlesztésénél merült fel. Bemutattunk optimális on-line algoritmusokat abban az értelemben, hogy a lehető legjobb versenyképességi arányt érték el, és bemutattunk egy jóval kifinomultabb algoritmust is, mely képes megtanulni a fizikai infrastruktúra felépítéséből adódó maximális várakozási idôt is, azaz a burst-ök várható hosszát. Egy szimulált mérés segítségével bemutattuk, hogy ez a tanuló algoritmus jól használható a valós körülmények között, akkor is ha nincs információnk a burst-ök várható hosszáról és lényegesen jobb hatékonysággal múködik az átlagos esetben, mint az optimális versenyképességi hányadossal rendelkező algoritmusok. Több további érdekes kérdés is felmerül. Érdekes lehet például más, bonyolultabb célfüggvények vizsgálata is. További érdekes kérdés, mivel ez a modell feltételezi, hogy az adatok tartalmazzák a burst_id-t, de néhány alkalmazásban nem kapjuk meg ezt az információt, hogy milyen algoritmusokat lehet alkalmazni abban az esetben ha a csomagok nem tartalmazzák a burst-id adattagokat. 


\section{Összegzés}

Disszertációmban az on-line algoritmusok területén, a számítógépes hálózatok és adatfeldolgozás on-line problémáival foglalkozom, így az az elmúlt néhány évben ezen területeken végzett kutatásaim eredményeinek összefoglalását tartalmazza. A téma korszerúségét és fontosságát a területen megjelent nagy számú publikáció is mutatja.

Az első fejezetben az on-line algoritmusok témakörének alapfogalmait és a versenyképességi elemzés alapjait mutatom be.

A 2. fejezetben a nyugtázási problémát ismertetem, majd definiálom a probléma vizsgálatára legáltalánosabban használt matematikai modellt, és bemutatok egy alapvetô optimális algoritmust, ami nem csak a 2. fejezetben bemutatott problémák megoldásának alapötletéül szolgál, hanem késóbb a 3. és 5. fejezetben is fontos kiindulópont. Bemutatok a problémára egy új idô szerinti elôre nézô félig on-line változatot. A problémát vizsgáljuk mindkét a szakirodalomban használt célfüggvény esetén. Az $f_{\max }$ célfüggvény esetén egy optimális félig on-line algoritmust adunk meg, abban az értelemben, hogy a lehető legkisebb versenyképességi hányadost éri el. Az $f_{\text {sum }}$ célfüggvény esetén egy $1+O(1 / c)$ vesenyképes algoritmust adunk meg, ahol $c$ az elörenézô intervallum hossza. Szintén igazoljuk, hogy nincs olyan félig on-line algoritmus, mely versenyképessége kisebb, $\operatorname{mint} 1+\Omega\left(1 / c^{2}\right)$.

A 3. fejezetben a legrosszabb eset elemzésen túllépve, a 2. fejezetben már tárgyalt problémákat véletlenül generált és valós adatokon vizsgáljuk. 
Ismertetünk egy-egy új, az optimális paraméter tanulásán alapuló algoritmust, és megvizsgáljuk, hogy ezek az algoritmusok milyen hatékonysággal múködnek. Megmutatjuk, hogy átlagos esetben ezek az algoritmusok a minimális versenyképességi hányados értékéból adódónál lényegesen jobb célfüggvény értéket is elérhetnek.

A 4. fejezetben egy másik on-line problémának, a visszautasításos on-line ütemezésnek a vizsgálatát végezzük el, az elôző fejezetben tárgyalt módszerhez hasonlóan. Bemutatjuk a probléma megoldására már ismert mohó algoritmust, majd egy annál lényegesen jobb, versenyképesség szempontjából optimális algoritmust is. Ebból kiindulva bemutatunk egy, az optimális paraméter-érték tanulásán alapuló algoritmust és megvizsgáljuk, hogy generált és valós adatokon az új algoritmusunk milyen hatékonysággal múködik. A tesztek eredményeit értékelve megmutatjuk, hogy az új algoritmus minden inputra az optimálishoz közeli hatékonysággal múködik.

Az 5. fejezetben egy új, a valós idejû pozíciómeghatározás fejlesztése közben felmerült problémát, egy on-line klaszterezési problémát mutatunk be. Megadunk két, a probléma kezelésére jól használható matematikai modellt, és ezekre optimális on-line algoritmusokat fejlesztünk ki, abban az értelemben, hogy azok a lehető legkisebb versenyképességi hányadossal rendelkeznek. Továbbá megadunk egy a gyakorlat szempontjából jól használható algoritmust a probléma megoldására és generált és valós inputokon elemezzük az új algoritmusok hatékonyságát. Belátjuk, hogy esetünkben, és az elôző két fejezet eredményeivel egybevetve talán általában is, a paraméter tanulásán alapuló algoritmusok jól használhatók 
abban az esetben, ha nincs elôzetes információnk az input egyes paramétereiről, és a gyakorlatban nem feltétlenül a versenyképességi elemzés szempontjából optimális algoritmus a leghatékonyabb is egyben. 


\section{Summary}

In this dissertation we deals with some online problems of computer networks and online scheduling with rejection. We summarize the results of our research that has been done over the past few years. The timeliness and relevance of these topics are shown by the large number of publications in the field.

Chapter 1 introduces the basic concepts of the field of online algorithms and the definitions of competitive analysis. Chapter 2 details the data acknowledgement problem and defines the most commonly applied mathematical model for it. We present here a well-known alarming algorithm which has the smallest possible competitive ratio. This algorithm will also play an important role later in Chapters 3 and 5 . Then we consider a new semi online version of the problem which is based on the time lookahead property. We study both of the usually objective functions. In the case of objective function $f_{\max }$ we present an optimal semi online algorithm in the sense that achieves the smallest possible competitive ratio. In the case of objective $f_{\text {sum }}$ we give an algorithm which is $1+O(1 / c)$-competitive where $c$ is the length of the lookahead interval, and we show that no semi online algorithm can have smaller competitive ratio than $1+\Omega\left(1 / c^{2}\right)$.

In Chapter 3 we study the data acknowledgment problem and the data acknowledgment problem with lookahead in the average case. A pair of new algorithms are introduced, which are based on learning some optimal parameters. The efficiency of the algorithms is investigated on randomly generated and also on real data. It is pointed out that on average, these 
algorithms can attain a much better objective function value than the algorithms which have the smallest possible competitive ratio.

In Chapter 4 we study an another online problem, the online scheduling with rejection. We use similar methods to the methods discussed in the previous chapter. First we recall a greedy algorithm and a more sophisticated RTP (reject total penalty) algorithm for the solution of the problem. RTP achieves the smallest possible competitive ratio Using the idea of parameter learning we introduced a new online algorithm called PAROLE for the solution of the problem. The efficiency of the algorithms is again investigated on randomly generated and also on real data. Using the results of the tests, it is demonstrated that the new algorithm works with near-optimal efficiency with all inputs.

Chapter 5 introduces an online clustering problem arisen during the development of a real-time position location system. Two mathematical models - which can be efficiently used to tackle the problem are provided. In both models we found optimal online algorithms which achieves the smallest competitive ratio. optimality based on their competitiveness. We also define a further algorithm based on parameter learning. The algorithms are evaluated in the simulation system of the Fraunhofer Institute and again we obtain that the new algorithm has better performance on real data than the ones with the best competitive ratio. 


\section{Hivatkozások}

[1] S. Albers and H. Bals. Dynamic TCP acknowledgement: Penalizing long delays SIAM J. Discrete Math. 19(4) 938-951, 2005.

[2] S. Albers, and B. Schrôder: An Experimental Study of online Scheduling Algorithms. ACM Journal of Experimental Algorithms, article 3, 2002.

[3] L. Allulli, G. Ausiello, L. Laura, On the power of lookahead in online vehicle routing problems Lecture Notes in Computer Science 3595, Springer, Berlin, 728-736, 2005.

[4] Y. Bartal, S. Leonardi, A. Marchetti-Spaccamela, J. Sgall, and L. Stougie: Multiprocessor scheduling with rejection, SIAM Journal on Discrete Mathematics, 13:64-78, 2000.

[5] V. Bilo, M. Flammini and R. Giovannelli: Experimental analysis of online algorithms for the bicriteria scheduling problem, J. Parallel Distrib. Comput., 64:1086-1100, 2004.

[6] E. Bittner, Cs. Imreh, J. Nagy-György, The online k-server problem with rejection, submitted to Discrete Optimization

[7] A. Borodin, R. El-Yaniv, Online Computation and Competitive Analysis Cambridge University Press, 1998. 
[8] M. Brugger, T. Christ, F. Kemeth, S. Nagy, M. Schaefer, M.M. Pietrzyk, The FMCW technology-based indoor localization system, Proceedings of Ubiquitous Positioning Indoor Navigation and Location Based Service (UPINLBS), Helsinki, Finnland, 2010 pp. 1-6.

[9] M. Brugger, F. Kemeth, Locating rate adaptation by evaluating movement specific parameters, Proceedings of 2010 NASA/ESA Conference on Adaptive Hardware and Systems (AHS), Anaheim, USA, 2010 pp. 127-133.

[10] J. R. Correa and M. Wagner: LP-Based online Scheduling: From Single to Parallel Machines Mathematical Programming, to appear (prelinimary version in Proceedings of IPCO 2005 LNCS 3509, 186209).

[11] Gy. Dósa and Y. He: Scheduling with machine cost and rejection, Journal of Combinatorial Optimization, 12(4):337-350, 2006.

[12] Gy. Dósa, Y. He, Bin packing problems with rejection penalties and their dual problems, Information and Computation, 204, 2006, $795-815$

[13] Gy. Dósa, Cs. Imreh, On-line algoritmusok Typotex 2011.

[14] D. R. Dooly, S. A. Goldman, S. D. Scott: Online analysis of the TCP acknowledgment delay problem. J. ACM 48(2) 243-273, 2001.

[15] D. V. Engels, D. R. Karger, S. G. Kolliopoulos, S. Sengupta, R. N. Uma and J. Wein: Techniques for scheduling with rejection, Journal of Algorithms, 49:175-191, 2003. 
[16] L. Epstein and J. Sgall: Approximation schemes for scheduling on uniformly related and identical parallel machines, Algorithmica, 39(1):4357, 2004.

[17] L. Epstein, A. Kesselman: On the remote server problem or more about TCP acknowledgments. Theoretical Computer Science 369(1-3) 285-299, 2006.

[18] L. Epstein, A. Levin, G. J. Woeginger, Graph coloring with rejection, Journal of Computer and System Sciences, 77(2), 2011, 439-447.

[19] L. Epstein, Bin packing with rejection revisited, Algorithmica, 56(4), 2010, 505-528.

[20] L. Epstein, Cs. Imreh, A. Levin, J. Nagy-György, Online File Caching with Rejection Penalties, Algorithmica, to appear, doi 10.1007/s00453013-9793-0

[21] A. Fiat, G.J. Woeginger (eds.) Online algorithms: The State of the Art, LNCS 1442, Springer-Verlag, Berlin, 1998.

[22] J. S. Frederiksen, K. S. Larsen, J. Noga, P. Uthaisombut: Dynamic TCP acknowledgment in the LogP model. Journal of Algorithms 48(2) 407-428, 2003.

[23] R. L. Graham: Bounds for certain multiprocessor anomalies, Bell System Technical Journal, 45:1563-1581, 1966.

[24] Cs. Imreh, An online scheduling algorithm for a two-layer multiprocessor architecture, Acta Cybernetica, 15, (2001), 163-172 
[25] Cs. Imreh: Scheduling problems on two sets of identical machines, Computing, 70:277-294, 2003.

[26] Cs. Imreh: Competitive analysis, Algorithms of Informatics Volume 1, pages 395-428, Budapest 2007.

[27] Cs. Imreh, T. Németh, On time lookahead algorithms for the online data acknowledgement problem, 32nd International Symposium on Mathematical Foundations of Computer Science, LNCS 4708, Cesky Krumlov, 2007, pp. 288-297.

[28] Cs. Imreh and T. Németh, Parameter learning algorithm for the online data acknowledgment problem, Optim. Methods Softw., 26, 3 (2011) 397-404.

[29] A. R. Karlin, C. Kenyon and D. Randall, Dynamic TCP acknowledgement and other stories about e/(e-1), Algorithmica 36 (2003), pp. 209-224.

[30] J. Nagy-György and Cs. Imreh, Online scheduling with machine cost and rejection, Discrete Applied Mathematics, 155: 2546-2554, 2007.

[31] T. Németh, Cs. Imreh, Parameter learning online algorithm for multiprocessor scheduling with rejection, Acta Cybernetica 19(1) (2009), pp. 125-133.

[32] T. Németh, B. Gyekiczki, Cs. Imreh, Parameter Learning in Lookahead Online Algorithms for Data Acknowledgment, IEEE International Symposium on Logistics and Industrial Informatics, 2011 
[33] T. Németh, S. Nagy, Cs. Imreh Online data clustering algorithms in an RTLS system Acta Universitatis Sapientiae, Informatica, 5, 1 (2013) 5-15.

[34] J. Noga, S. S. Seiden, G. J. Woeginger, A faster off-line algorithm for the TCP acknowledgement problem. Information Processing Letters 81(2) 71-73, 2002

[35] S.S. Seiden, A guessing game and randomized online algorithms, Proceedings of STOC 2000, 592-601.

[36] S. S. Seiden: Preemptive Multiprocessor Scheduling with Rejection, Theoretical Computer Science, 262:437-458, 2001.

[37] J. Sgall: Online scheduling, Online algorithms: The State of the Art, LNCS 1442, pages 196-231, Berlin, 1998, Springer Verlag.

[38] W. R. Stevens, TCP/IP Illustrated, Volume I. The protocols, Addison Wesley, Reading, 1994 